Check for updates

Cite this: RSC Adv., 2019, 9, 39201

\title{
Concentrations of TENORMs in the petroleum industry and their environmental and health effects
}

\author{
Mohsen M. M. Ali, (D) ab Hongtao Zhao, ${ }^{* a}$ Zhongyu Li $^{\mathrm{a}}$ and Najeeb N. M. Maglas ${ }^{c}$
}

Crude oil and its products and wastes are among the significant sources of naturally occurring radioactive materials (NORMs). These materials may be enhanced to high levels due to technological and human activities, which are called technologically enhanced naturally occurring radioactive materials (TENORMs). Thus, the average radioactivity of these radionuclides sometimes exceeds the exemption level of $10000 \mathrm{~Bq} \mathrm{~kg}^{-1}$, which is recommended by the IAEA's safety standards. TENORMs in the oil and gas industry may generate greater radioactivity levels, which eventually represents potential environmental and health risks. This will require continuous attention by monitoring and surveillance during routine processes in the petroleum industry. In this paper, a comprehensive review of the published literature is conducted to evaluate the TENORM concentrations in the oil and gas industry. Moreover, their environmental and health hazards in different regions of the world are discussed.

Received 5th August 2019

Accepted 31st October 2019

DOI: $10.1039 / \mathrm{c} 9 \mathrm{ra06086c}$

rsc.li/rsc-advances

phosphate rocks, fertilizers, slag, and phosphorus from

\section{Introduction}

At present, various environments suffer from the excessive accumulation of radioactive pollutants and their hazardous results, where radionuclides naturally decay. Examples of such radionuclides are: ${ }^{226} \mathrm{Ra},{ }^{228} \mathrm{Ra},{ }^{222} \mathrm{Rn},{ }^{210} \mathrm{~Pb},{ }^{40} \mathrm{~K}$ etc., which decay along with many other man-made radionuclides. ${ }^{1-4}$ Approximately $80 \%$ of human exposures to radiation comes from the radioactive sources that naturally occur, which may lead to several harmful effects on humans, animals, or the environment. ${ }^{5-10}$ Materials that contain large amounts of natural radionuclides are referred to as naturally occurring radioactive materials (NORMs). They are in the crust of the earth and we are exposed to them every day. NORMs are an integral part of the planet, our bodies, the food we eat, the air we breathe, the places we live and work, and the products we use. Treatment of some natural resources enhances naturally occurring radionuclides to the extent that they may pose risks to humans and the environment. These by-products are named as follows: technically enhanced naturally occurring radioactive materials (TENORMs). The majority of radionuclides are found in TENORMs, uranium and thorium chains. ${ }^{11-14}$ Therefore, many non-nuclear industries are forced to take radiation protection measures. Examples of raw materials, products and waste that can cause problems for the non-nuclear industry are zircon sand used in ceramic industry;

\footnotetext{
${ }^{a}$ Fundamental Science on Nuclear Safety and Simulation Technology Laboratory, Harbin Engineering University, Harbin 150001, China. E-mail: mohsenzmra7777@ gmail.com; mohsenzmra7777@hrbeu.edu.cn; Tel: +86 13030042632

${ }^{b}$ National Atomic Energy Commission-Yemen, Sana'a, Yemen

'Physics Department, Faculty of Applied Science, Thamar University, Thamar, Yemen
} phosphate industry; fly ash from electricity production; and metrology and sludge from oil and gas production. In these substances, the activities specified are often higher than $1 \mathrm{~Bq}$ $\mathrm{g}^{-1}$, and for more fly ash and some oil/gas scales, the radioactivity can reach $1000 \mathrm{~Bq} \mathrm{~g}^{-1} \cdot{ }^{11-17}$ In this study, the focus is on the TENORM produced in the oil and gas industry. High concentrations of background radiation in crude oil were reported for the first time by Hempstead and Burton between 1920 and 1930; also the term has been reported by Russian and German researchers. ${ }^{18-22}$ Preliminary assessments of occupational radiation exposure were recorded in the oil and gas industries a few decades ago, when Kolb and Wojcik discovered TENORMs in petroleum in $1985 .^{3,22,23}$ They measured the dose rate at many oil field sites in northern Albania and determined the values of concentrations of these radionuclides: ${ }^{228} \mathrm{Ra},{ }^{226} \mathrm{Ra}$ and ${ }^{222} \mathrm{Rn}^{3,20-23}$ the first official survey from the point of view of radiation protection was conducted in 1970s and early 1980s, when the TENORMs were detected in the North Sea Oil Platforms. ${ }^{24-26}$ Several types of "scattered TENORM wastes," such as scales, sludge, and produced water, were found in the petroleum industries, where the radium bearing scale was discovered in North Sea oil. ${ }^{24-27}$ Thus, the accumulation of radium in US oil field equipment became apparent for the first time in the 1980s, when scrap metal traders began routinely detecting unacceptable levels of radioactivity in pipeline shipments. ${ }^{22-26}$ Since then, many oil and gas industries have sought to effectively determine the TENORM problems in the oil fields and develop techniques for forecasting, protection, correcting, and eliminating TENORMs from the fields and facilities..$^{24-26,28}$ The TENORMs concentrations in the wastes of the petroleum industries were studied 
and reported by many researchers from different regions of the world.

The release of radioactive particles from the radionuclides might be one of the potential bases of energy related with the conversion of the organic materials to oil in the long term, where naturally occurring radioactive elements dissolve at highly depressed concentrations through the natural interactions among soil, rock, and water.9,29-31 Therefore, oil fields may contain many natural radionuclides such as ${ }^{228} \mathrm{Ra},{ }^{226} \mathrm{Ra},{ }^{224} \mathrm{Ra},{ }^{210} \mathrm{~Pb}$, and ${ }^{40} \mathrm{~K}$ which are transported to the surface of the earth and may include high levels of radioactivity. ${ }^{23,32-34}$ Many oil fields are rich in chloride, thus enhancing their relative solubility. When oil is pumped from the depths of the wells to the surface, it also produces water. This produced water is extracted from oil containing volatile metal materials, some of which are free of active substances due to the presence of radium isotopes and their decay products..$^{27,35-38}$ The initial products of the oil and gas are usually dry. When the produced water is brought to the surface, the decrease in temperature and pressure allows the use of melted soluble radioactive substances in this water. ${ }^{27}$ Elements containing natural radionuclides appear in the form of complex compounds, such as sulfates, silicates, and carbonates, which are present in scale and sludge. ${ }^{38}$ These sediments are formed at sufficient temperatures with oil/ water pumping to the surface. ${ }^{35-37}$ Thus, the quantity of precipitation depends on the chemical-physical properties of this water.

The uncontrolled release of radioactivity related to TENORM levels may pollute the environment and endanger human health. Hazardous radiation may enter the human body through various ways, of exposure that are classified either internal or external, such as absorption, wounds, inhalation and ingestion..$^{22,27,39,40}$ Controls have been adopted for TENORMs to avoid the risk of these wastes, efforts to shield radiation should be made to protect workers and the public, and any regulations set in place for radiological protection must consider the additional risks that exceed the exposure to native natural radioactivity. ${ }^{22,27,39,40}$ The IAEA has published the overall radiological safety criteria that depend on the recommendations of the International Commission on Radiation Protection. These criteria were also recommended for adoption by the European Commission as the basic safety standards (BSS) by all European society countries..$^{20,22,25,39-41}$ Several countries have implemented their own regulations on TENORMs based on these recommendations. The concentrations of TENORMs in oil and gas industries, ${ }^{25,39-41}$ measured globally and adopted by IAEA are shown in Table 1. It is noted from the table that ${ }^{226} \mathrm{Ra}$ is the most concentrated isotope, especially in the scales. Therefore, scales are considered one of the most dangerous waste of the petroleum industry.

Studies on the radioactivity of the oil and gas industries with a focus on ${ }^{226} \mathrm{Ra}$ and ${ }^{228} \mathrm{Ra}$, in petroleum wastes reported in, ${ }^{24,25,42-47}$ were presented in previous literature reviews. However, this study is very detailed. On the one hand, the study focused on most natural and artificial radionuclides. On the other hand, most previous studies on the presence of TENORMs in petroleum products and wastes and samples from the environment surrounding oil and gas industry facilities have been studied. This work aims to review studies conducted on the
TENORMs radioactivity resulting from the oil and gas industries in different regions of the world in addition to its environmental and health effects. The issues mentioned in previous studies confirm that an update is necessary, and new methods of managing, evaluating, and eliminating the potential risks of TENORMs must be developed, which is part of an integrated system for the administration of professional safety.

\section{Evolution of the term TENORMs}

To understand the naturally occurring radioactive materials in the solids, liquids and gases generated by natural processes, many researchers have used many of the terms that symbolize these materials. The industrial enhancement of TENORMs in the petroleum industries are created in many different ways as a result of enhanced oil recovery and other industrial practices used during petroleum industry activities. For this reason, many terms that symbolize these activities and processes have evolved over time. K. Al Nabhani et al. ${ }^{19}$ have defined some terms used by many researchers, which include: $\mathrm{NOR}^{48-50}$ is the abbreviation for the description of Naturally Occurring Radionuclides, which is explained by its concentration on radioactive elements and not on the materials in which radionuclides are stored. HINAR ${ }^{51,52}$ is the abbreviation for the definition of High Natural Radioactivity, which is interpreted by a focus on areas affected by high natural radioactivity. $\mathrm{NARM}^{53-55}$ is the abbreviation for the definition of Naturally Accelerator-Produced Radioactive Materials, which is interpreted by naturally radioactive materials being artificially produced during the operation of atomic particle accelerators. $\mathrm{ENOR}^{19,56}$ is the abbreviation for a definition of Enhanced Naturally Occurring Radioactivity, which is interpreted by naturally occurring radioactivity technologically enhanced. TENR ${ }^{56-61}$ is the abbreviation for a definition of Technologically Enhanced Natural Radioactivity, which is interpreted by natural radioactivity technologically enhanced. NORM ${ }^{9,33,62,63}$ is the abbreviation for the definition of Naturally Occurring Radioactive Material, which is interpreted by all solid radioactive materials being created by the natural process. This definition is the most common term used by researchers and specialists. TEN$\mathrm{ORM}^{19,57-64}$ is the abbreviation for the definition of Technologically Enhanced Naturally Occurring Radioactive Materials, which is interpreted by radionuclide content of naturally radioactive materials is enhanced by manmade procedures (common in industries and highly used). This term is considered the most important radiological point of view because it distinguishes between these naturally occurring radioactive substances and those that are promoted through human activity in many industries and fields. In this study, this naming was adopted because it is more comprehensive and capable of describing radionuclides in petroleum industries.

\section{TENORMs sources in the oil and gas industries}

Radioactive materials have been an integral part of the earth's crust ever since the earth was formed. Where the natural 
Table 1 Concentrations of natural radioactive materials in petroleum industry $85,90,228,278$

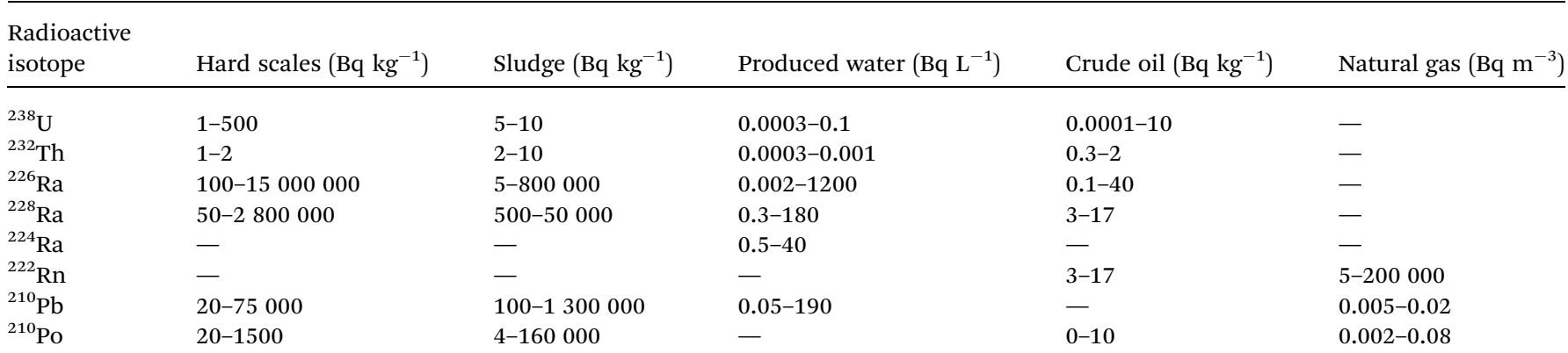

radiation chains are found in nature: ${ }^{65-68}{ }^{238} \mathrm{U}$ series form $99.27 \%$ of natural uranium, ${ }^{235} \mathrm{U}$ series accounts for $0.725 \%$ of natural uranium, ${ }^{234} \mathrm{U}$ is a very small percentage $(0.005 \%)$ of natural uranium and ${ }^{232}$ Th series and ${ }^{40} \mathrm{~K} .{ }^{6,69,70}$ These chains are present in the oil and gas fields in the ground. These radioactive materials are transported with liquids from the oil fields to the surface of the earth. ${ }^{7-74}$ It's known that the atoms of these chains are unstable, which means that they undergo spontaneous self-transformation so that their atom becomes more stable. This process of transformation is called radioactive decay. Natural radioisotopes are present in oil and gas industries with varying concentrations. ${ }^{75-77}$ In certain places of production and processing facilities, these isotopes accumulate and lead to enhanced levels of radioactivity. These materials are treated as a closed radiant source as long as they are within the parts of the facility, and when opening one of the parts of the facility, they are treated as an opened radiant source. ${ }^{64,78-81}$ Natural radioactive materials are found in oil and gas basins where other mineral elements are in different concentrations and these materials are released with the production fluids during the extraction processes as shown in Fig. 1:

It is noted from Fig. 1 that the origin of ${ }^{226} \mathrm{Ra},{ }^{228} \mathrm{Ra}$ and ${ }^{222} \mathrm{Rn}$ are progeny resulting from the dissolution of the parent isotopes such as ${ }^{238} \mathrm{U}$ or ${ }^{232} \mathrm{Th}$, which is found in the geological strata below the surface of the earth, especially in the clay mud rocks, ${ }^{\mathbf{8 1 , 8 3 - 8 5}}$ which researchers found in previous studies. ${ }^{\mathbf{5 0 , 8 5 - 8 7}}$ As both uranium and thorium salts are part of these layers, they do not dissolve significantly in pelvic fluids (fresh water, salt water, oil and gas). While salts of radium dissolve in water and move from these layers to the surface of the earth with oilrelated water. ${ }^{\mathbf{8 2} 87,88}$ The quantities of radium present in the produced water and associated with the oil depend on the nature and quantity of these rocks and their content of uranium and thorium, in addition to the physical and chemical conditions such as pressure, temperature and pH. Fig. 2 shows the recombination and distribution of natural radioactive substances in different oil liquids by extraction processes.

\section{Concentration of TENORM in petroleum products}

Petroleum is a broad concept and includes crude oil and its products, natural gas, and others. The term "petroleum" refers only to crude oil but can be sometimes used to describe any solid, liquid, or gaseous hydrocarbons. ${ }^{23,91}$ Crude oil is a kind of naturally flammable liquid and can be found in natural reservoirs in geological formations below the surface of the earth. Such oil consists of a complex mixture with different molecular weights of hydrocarbons and other organic liquid compounds. ${ }^{41,91,92}$ Most petroleum components are fossil fuels formed when considerable dead organisms, usually zooplankton and algae, are buried under sedimentary rocks and subject to intense temperature and pressure. ${ }^{\text {11,92,93 }}$ Then, petroleum is brought to the surface and its components are easily separated by the boiling point property into a substantial number of consumer petroleum products..$^{23,41,91-94}$ These products include diesel, benzene, gasoline, jet fuel, natural gas, kerosene, naphtha, plat format, flushing oil, asphalt, green coke, sulfur, oil slope, vacuum, unconverted oil, and chemical reagents used in plastics, lotions, treatments, and others. $^{\text {23,41,91-94 }}$ Petroleum is used in many industries, and 88 billion barrels per day are estimated to be consumed around the world.

The results of a study ${ }^{97}$ in the United States showing low concentrations of uranium in crude oils in the range of 0.0015$0.015 \mathrm{ppm}$ for uranium in crude oil is typical. In study, ${ }^{\mathbf{1}}$ the concentration of uranium in petroleum products in Saudi Arabia was reported to be $<-8.5 \mathrm{~Bq} \mathrm{~kg}^{-1}$ (see Table 2 for the rest of the studies). Evidently, the concentration of uranium is particularly low in raw oil and petroleum products. The reported radium isotopes in crude oil and products are also low. For example, the concentration of ${ }^{226} \mathrm{Ra}$ in Algerian crude oil in 95 is in the range of 6-20 Bq kg${ }^{-1}$. The maximum concentration of radium isotopes in Egyptian petroleum products was found in, ${ }^{111}$ wherein ${ }^{226} \mathrm{Ra}$ was in the average of $11512.8 \mathrm{~Bq} \mathrm{~kg}^{-1}$. Thus, ${ }^{232} \mathrm{Th},{ }^{40} \mathrm{~K}$, and other radioisotopes reported in previous studies in Table 2 are at low concentrations below the minimum value set by the IAEA, WHO, EPO, and others.

\section{Concentrations of TENORMs in petroleum wastes}

\subsection{Produced water}

Petroleum reservoirs include oil, gas and water in the pores of the earth rocks, where water quantities tend to vary. ${ }^{35,42,113}$ The extraction of petroleum is often accompanied by large 


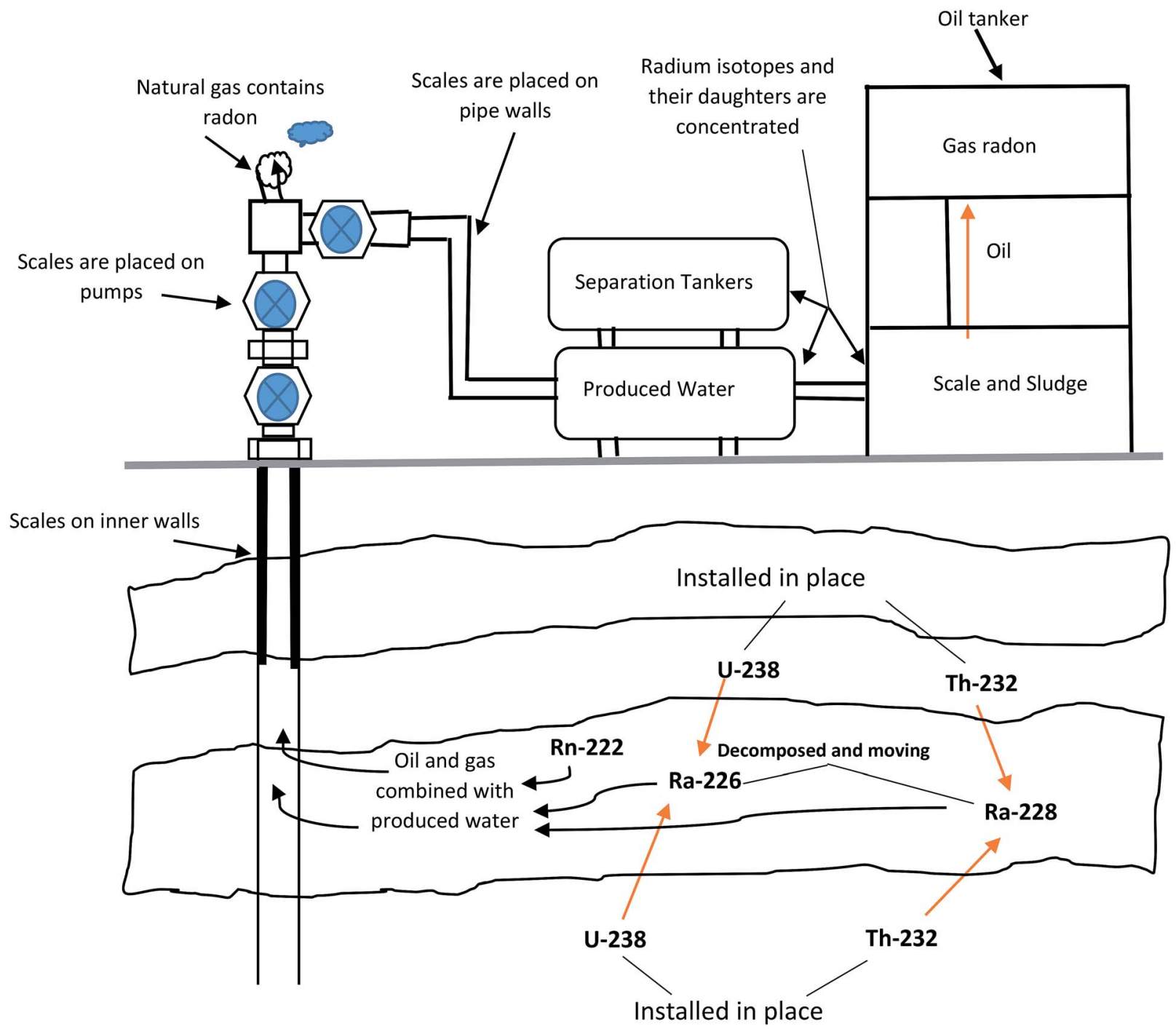

Fig. 1 The presence of natural radioactive materials in the oil industry. ${ }^{78,82,83}$

quantities of such water. This water is generally referred to as "produced water," "composition water", or "formation water", in oil fields. ${ }^{35,42,113,114}$ In many studies, gas production fields produce small amounts of produced water, while oil production fields produce large quantities of water. Thus, petroleum reservoirs contain formation water, which later becomes produced water when brought to the surface during the extraction of hydrocarbons. ${ }^{113-115}$ TENORMs are brought into the surface by the water formation that is produced when the pressure of the reservoir decreases with time while petroleum is extracted. The amount of TENORMs produced in the petroleum fields accompanying the petroleum extraction process are directly proportional to the size of produced water through the oil pumping process. ${ }^{34}$ That is, the water contaminated with TENORMs is considered a major waste of petroleum, and this proportion of radioactivity concentration from produced water usually ranges between 1-10 $\mathrm{Bq} \mathrm{kg}{ }^{-1} \cdot{ }^{25,116}$ The American Petroleum Institute ${ }^{29}$ reported that over 18 billion barrels of petroleum liquids is produced per year in the United States compared with the gross crude oil size of 2.5 billion barrels, which is equal to 400 million cubic meters. The gross of produced water accounted for $91 \%$ of what considered to be a waste. ${ }^{117-119}$ Alternatives to seawater injection are the reinjection of produced water or the injection of water from nearby formations. ${ }^{20,35,44,119,120}$ The vast majority of produced water from the underground is usually disposed by injection into the ground either in the extraction or in the disposal wells. In marine oil boreholes seawater usually injected to preserve the pressure at a certain level to ease the production process. In addition to that the produced water is already in the hole beside the oil. In the latter case, the produced water is usually salty and consist high degree of chloride-ions which form with Radium chemical compounds, thereby Radium nuclides then transferred from geological rocks adjacent to the waters into the water itself. ${ }^{42,121-123}$ It is also very common that produced water might be dissolved with a mixture of organic compounds (e.g., scale inhibitors and corrosion added to hydrocarbons production, namely, residual chemical additives, organic acids, and 


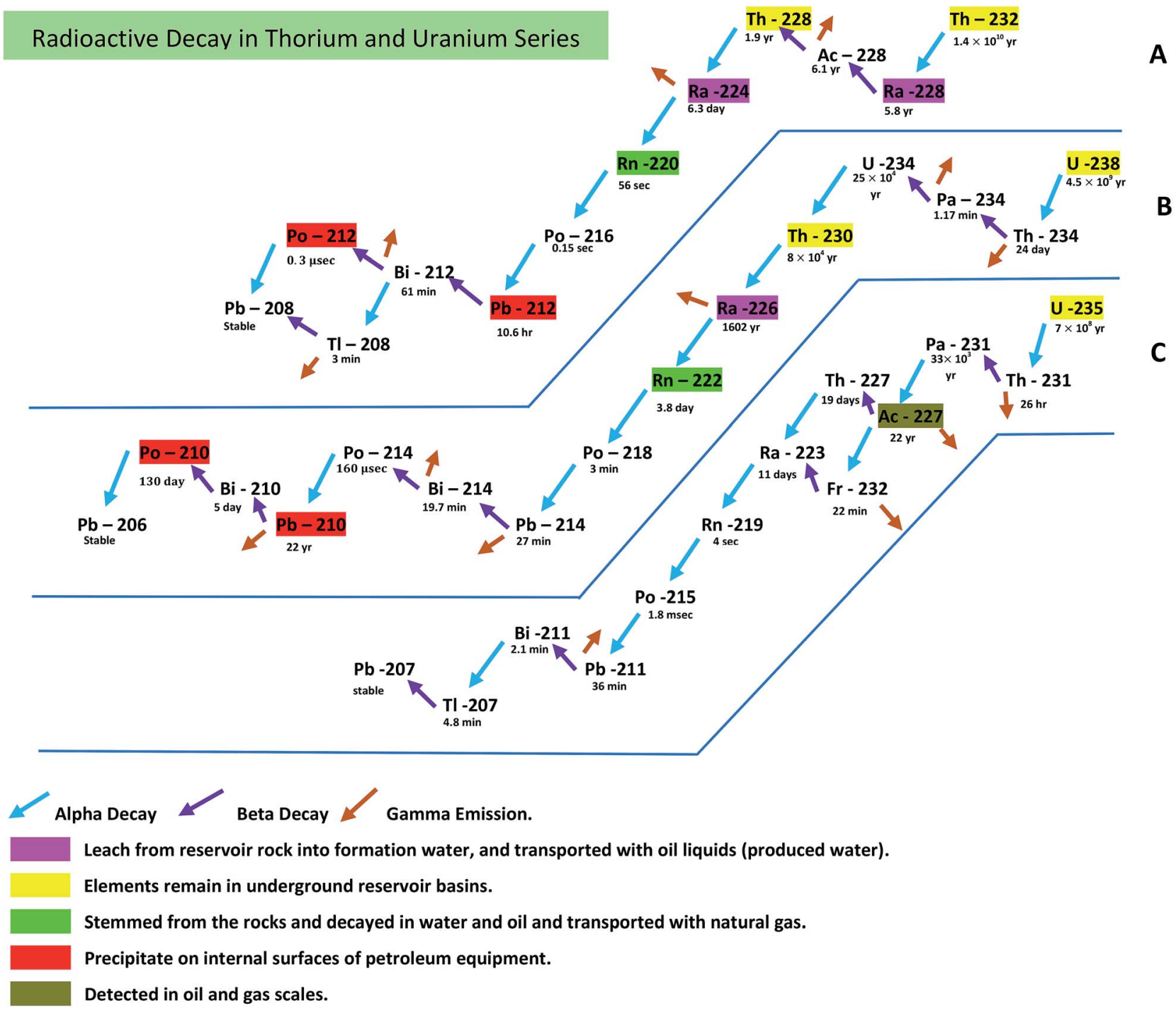

Fig. 2 Primordial radioactive decay series (A) ${ }^{232} \mathrm{Th}$, (B) ${ }^{238} \mathrm{U}$ and $(\mathrm{C}){ }^{235} \mathrm{U} \cdot{ }^{81,89}$

dissolved and dispersed hydrocarbons) and inorganic compounds (e.g., suspended particles, trace minerals, and dissolved salts). ${ }^{42,115,120-124}$ The existing organic compounds are composed of several groups, such as polycyclic aromatic hydrocarbons and alkylate phenols, which produce different effects in various organisms. The chemical decomposition of the produced water in the petroleum industries varies from one field to another. This difference relies on several factors such as operating conditions, type of produced hydrocarbon, age of the field towards the end of its productive life and geological characteristics of the surrounding rocks. ${ }^{42,117,122,124-137}$ The physical characteristics of the produced water is similar to sea water, especially if seawater is used for injection. Furthermore, the produced water contains partially dissolved mineral salts, along with radon or radium. Although uranium and thorium do not normally enter the sol, the stream of the produced water could be the major waste in terms of size resulting from the petroleum industries. Thus, the main source of TENORMs in the petroleum industries is the dissolved radionuclide in fluxes of produced water or suspended microscopic radionuclide as a result of the solubility \& mobility status of $U$ and $T h$, which is then transported to the surface with petroleum (Tables 3-5).

The activity concentrations of radium isotopes in most studies range from detection limits (DL) to less than $100 \mathrm{~Bq} \mathrm{~L}^{-1}$. Most results appear in the lowest range even in $10 \mathrm{~Bq} \mathrm{~L}^{-1}$. For example, concentrations of isotopic activity in the samples studied by ${ }^{\mathbf{1 1 9 , 1 3 0 , 1 3 6 , 1 3 9}}$ were less than $11.1 \mathrm{~Bq} \mathrm{~L}^{-1}$. Previous studies have shown that the main radionuclides involved are ${ }^{226} \mathrm{Ra}$ and ${ }^{228} \mathrm{Ra}$. Numerous researchers, such as, ${ }^{153}$ reported the presence of ${ }^{224} \mathrm{Ra}$ isotope in addition to ${ }^{226} \mathrm{Ra}$ and ${ }^{228} \mathrm{Ra}$ isotopes in the produced water in the In the Syrian, Turkish, Ukrainian and Ghanaian petroleum industries. Previous studies have shown that the $\mathrm{U}$ and Th do not extensively migrate during oil and gas extraction. Meanwhile, ${ }^{40} \mathrm{~K}$ is one of the abundant elements in produced water and reported in many studies. For example, ${ }^{40} \mathrm{~K}$ was expressed in produced water in the Egyptian, ${ }^{93}$ Tunisian, ${ }^{23}$ and Nigerian ${ }^{141,142}$ petroleum industries. ${ }^{137} \mathrm{Cs}$ is also present in the produced water of the US and Iraqi 
Table 2 Shows the range and mean values of the TENORMs concentrations in crude oil in diverse areas of the world, including recent data ${ }^{a}$

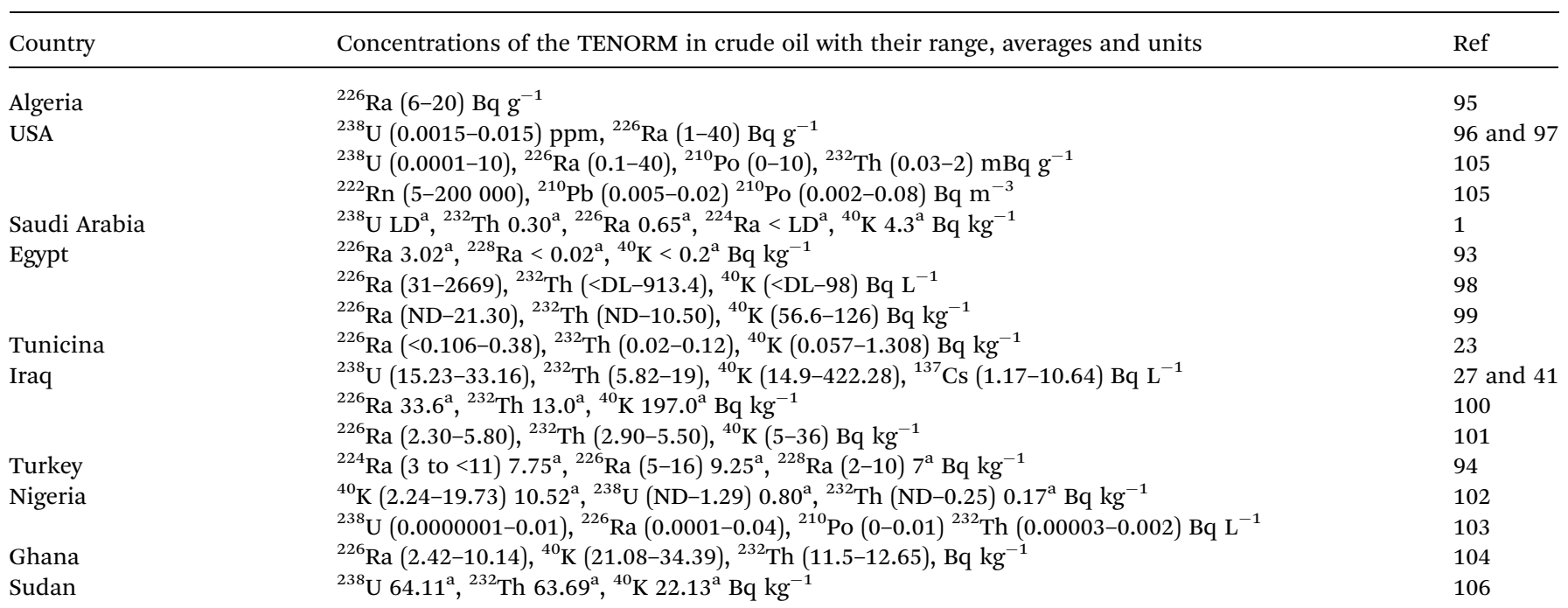

${ }^{a}$ ( ) the data between the brackets means the range/ ${ }^{\mathrm{a}}$ is the averages of concentration/LD $=$ lower than the detection limits.

petroleum industries. The available information on the concentrations of nuclides ${ }^{210} \mathrm{Po},{ }^{210} \mathrm{~Pb}$, and ${ }^{228} \mathrm{Th}$ in produced water is scarce compared with Ra isotopes. ${ }^{144}$ In 1997, the presence of radionuclides ${ }^{210} \mathrm{Po},{ }^{210} \mathrm{~Pb},{ }^{228} \mathrm{Th},{ }^{226} \mathrm{Ra}$, and ${ }^{228} \mathrm{Ra}$ were reported in produced water in minerals and hydrocarbons in oil and gas, discharge processes, and in environmental models associated with offshore production facilities in Texas/ Louisiana in the United States. In conclusion, the amounts of TENORM in the produced water in the oil and gas industry contribute to varying levels of pollution to the environment and slightly enhanced radioactivity in the terrestrial and marine environments. This condition may affect workers, the general public, plants, the surrounding environment, and marine organisms living near oil and gas platforms.

\subsection{Scales}

The scale in the oil and gas industry is one of the additional wastes composed of complex materials containing geological formations. ${ }^{37,155}$ Such materials are often composed of alkaline earth metals, such as silicate, carbonate, and sulfate, particularly $\mathrm{BaSO}_{4}, \mathrm{SrSO}_{4}$, and $\mathrm{CaCO}_{3} \cdot{ }^{37,68,129,155}$ These metals are produced by many physical and chemical processes, such as injection of water in reservoirs, pressure changes, temperature, evaporation in gas extraction tubes, $\mathrm{pH}$ balance, fluid expansion, changes in water acidity, inconsistent water mixing, different flow rates, and additives or impurities, during extraction..$^{37,45,116}$ Radium carbonate, radium sulfate and, in some cases, radium silicate, are formed due to radium deposition with sulfur, strontium, and calcium because of the similar chemical composition of these elements. . $^{37,42,45,68,116,129,155}$ The sudden changes in pressure and temperature and the acidity of the formation water brought to the surface are factors contributing to the accumulation of scales; moreover, at the process of injecting petroleum wells, mixing the sea water rich in sulfate with the composition water rich in salt solutions also increases the scales. ${ }^{34,129,156,157}$ Several studies have shown that the solubility variability of sulfates and carbonates, which can lead to the formation of the scale, is related to the physical and chemical processes in varying proportions as follows: (5\%), pressure changes $(10 \%)$, evaporation in extraction pipes, especially gas extraction $(10 \%)$, non-compatible water injection $(70 \%)$, and other factors (5\%). The scale composition is influenced by the re-entry of water into the wells to maintain production compression during field exploitation. ${ }^{44,45,83}$ Numerous factors, such as the amount of radium found below the surface of the earth, the components that make up the water, and the applied processes during extraction, can increase radium concentrations and radon in pipelines, equipment, and wastes in the gas and oil industry. Alkaline earth metal compounds, such as sulfates and carbonates, are deposited in oil and gas production equipment and produce the scale according to the following chemical equations:

$$
\begin{gathered}
\mathrm{Ca}^{2+}+\mathrm{CO}_{3}{ }^{2-} \rightarrow \mathrm{CaCO}_{3}, \\
\mathrm{Sr}^{2+}+\mathrm{SO}_{4}{ }^{2-} \rightarrow \mathrm{SrSO}_{4}, \\
\mathrm{Ba}^{2+}+\mathrm{SO}_{4}{ }^{2-} \rightarrow \mathrm{BaSO}_{4} .
\end{gathered}
$$

The American Petroleum Institute Dallas ${ }^{34,83,155}$ reported that scales in the oil and gas industry are often found inside pipes and tubes where concentrations are as high as tens of thousands of Bq g ${ }^{-1} .^{34,83,155}$ Therefore, the maximum concentrations of scale radioactivity are in the wellhead pipes and the production pipes near the good nozzle. However, the maximum size of the scale occurs in three areas, namely, the water lines associated with the separators (gas separated from oil and water), heater treaters (split the oil and water stages), and dehydrated gases, where sediments may accumulate in sizes up to 4 inch in thick. ${ }^{20,35,83}$ The mean concentration of 
Table 3 Shows the range and mean values of the TENORMs concentrations in petroleum products in diverse areas of the world, including recent data $^{a}$

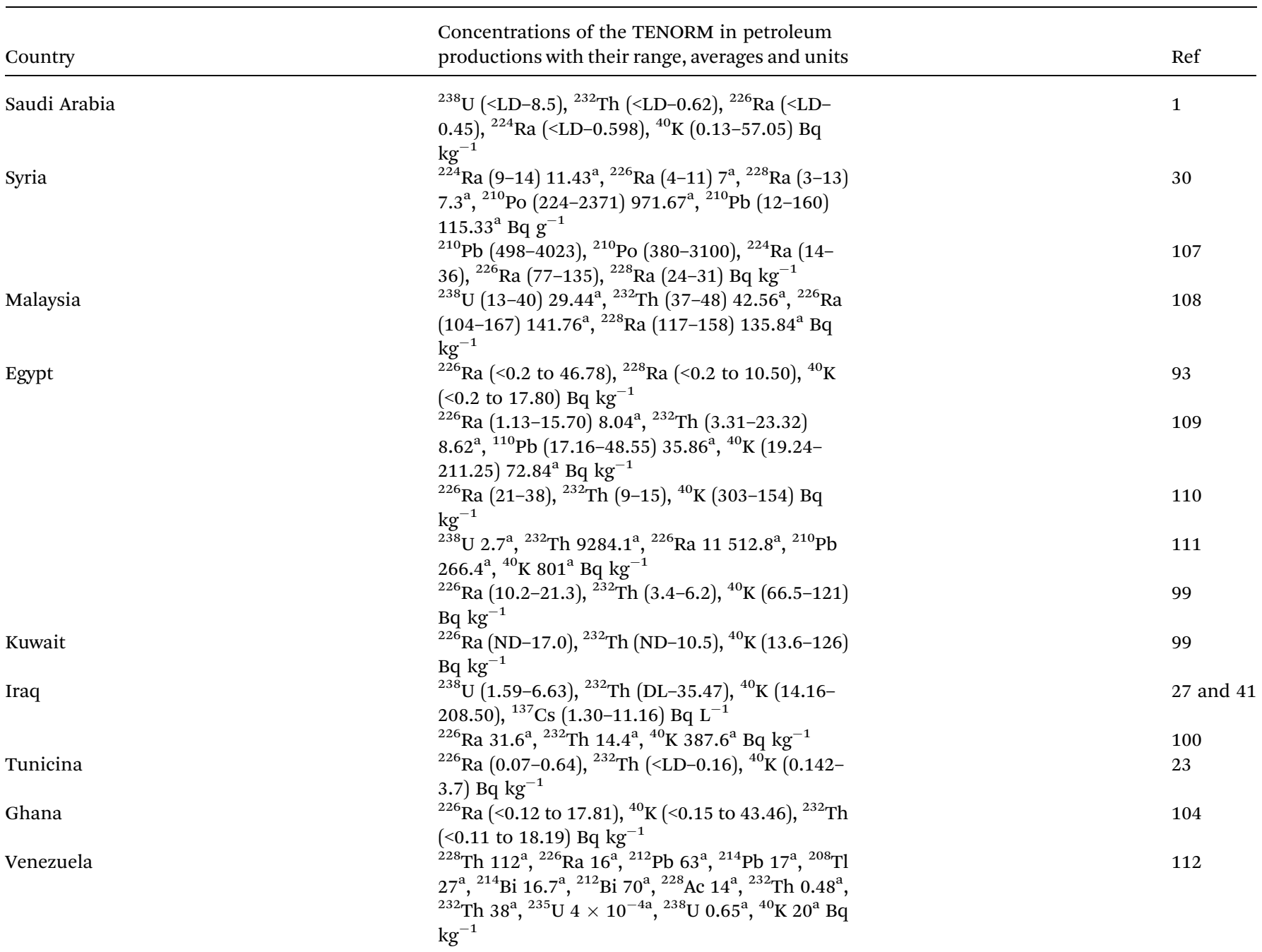

${ }^{a}$ ( ) the data between the brackets means the range/ ${ }^{\mathrm{a}}$ is the averages of concentration/LD $=$ lower than the detection limits.

radionuclides in the scale is $17.76 \mathrm{~Bq} \mathrm{~g}^{-1}$ (i.e., approximately $18000 \mathrm{~Bq} \mathrm{~kg}{ }^{-1}$ ), according to the latest estimate of the Environmental Protection Agency (EPA, 2017). This value can be much higher (up to $148000 \mathrm{~Bq}^{-1}$ ) or less depending on regional geology. The scale of wells and gaseous equipment can also contain radon offspring, such as ${ }^{210} \mathrm{~Pb}$ and ${ }^{210} \mathrm{Po}$ etc.

The survey included several studies on the scales generated in the oil and gas industry in different parts of the world. However, the scales were obtained in facilities, mostly in the section separators, oil and gas storage tanks, and pipelines. Some examples include the scales formed in the oil and gas fields in Italy, Egypt, Syria, Kazakhstan, ${ }^{20,30,128,181}$ and in other studies. The reported studies showed that the scale phenomenon is a result of the slow fluid flow rates, which facilitate the scale configuration process, and the large changes in pressure, temperature, and other physical and chemical factors on the liquids when passing through the machinery and equipment in the oil and gas industry. Some reported scales contain carbonate and are often offered in strange crystal forms, such as those in the oil-gas industry in Italy and Malaysia. Few scales contain carbonate, sulfate, and silicate, such as those of the oil plants reported in Brazil, North Africa (Tunisia), and Egyptian oil industry. However, the scale composition may contain some sulfur compounds, such as those reported in the Tunisian, Congo, and Saudi Arabia oil industries. Previous studies reported that many scales are formed in the oil and gas industry. The main types of scales are $\mathrm{BaSO}_{4}, \mathrm{SrSO}_{4}$, and $\mathrm{CaSO}_{3}$. The most common scale is $\mathrm{BaSO}_{4}$, also known as barite, which has the form of crystalline powder and exhibits various features (e.g., white color) that can vary depending on the crystalline impurities during configuration, high densities, and chemically inert and insoluble in water..$^{20,23,41,128,137,159,170}$ It is observed that a significant radioactivity in some samples taken from different areas in Indonesia, having higher concentrations may be due to the chemical behavior of radium and thorium elements in the deep aquifer filling process, as well as the geological nature of 
Table 4 Shows the typical ranges or mean values of concentrations of TENORMs in produced water in many oil fields worldwide, including recent data ${ }^{a}$

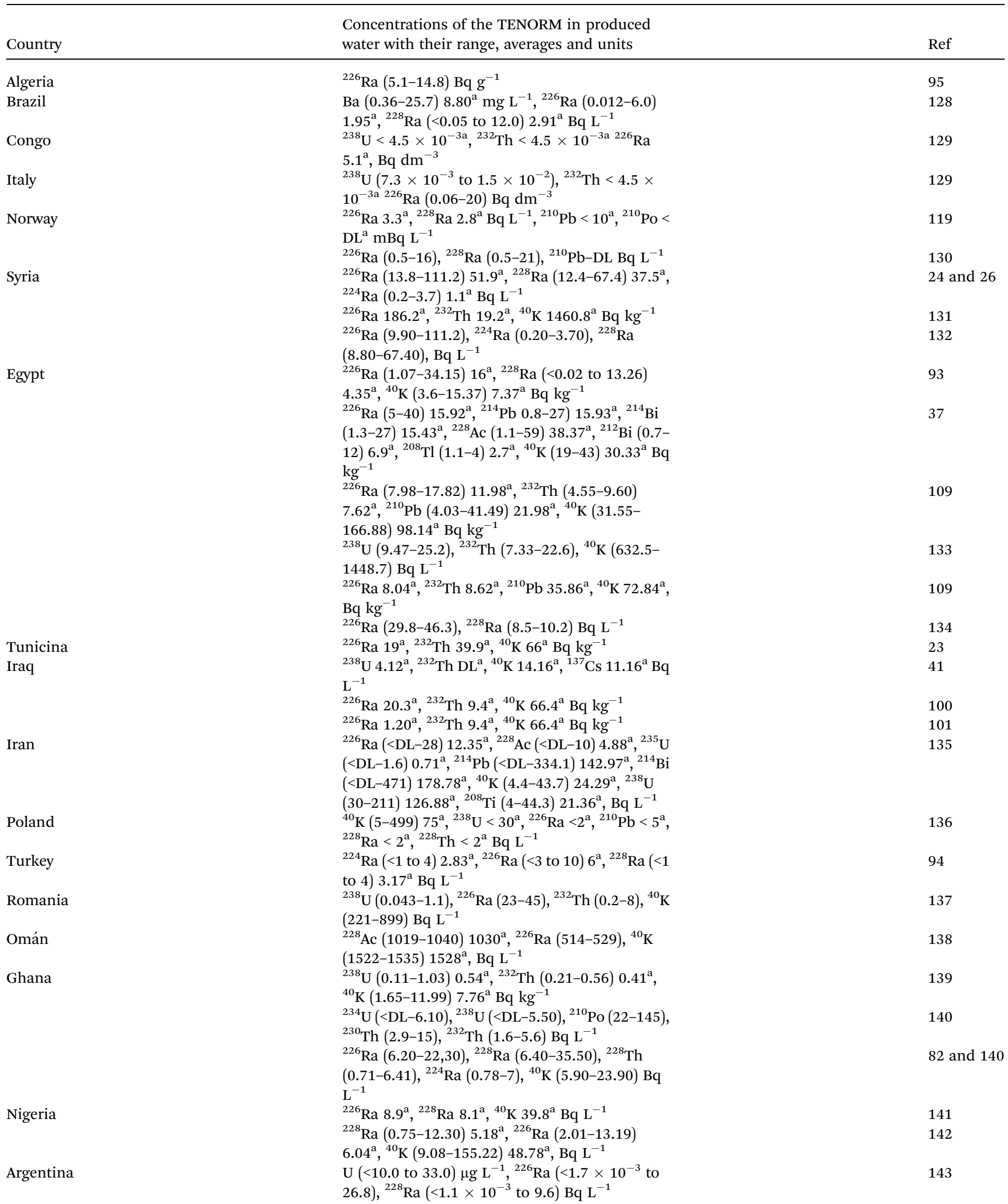


Table 4 (Contd.)

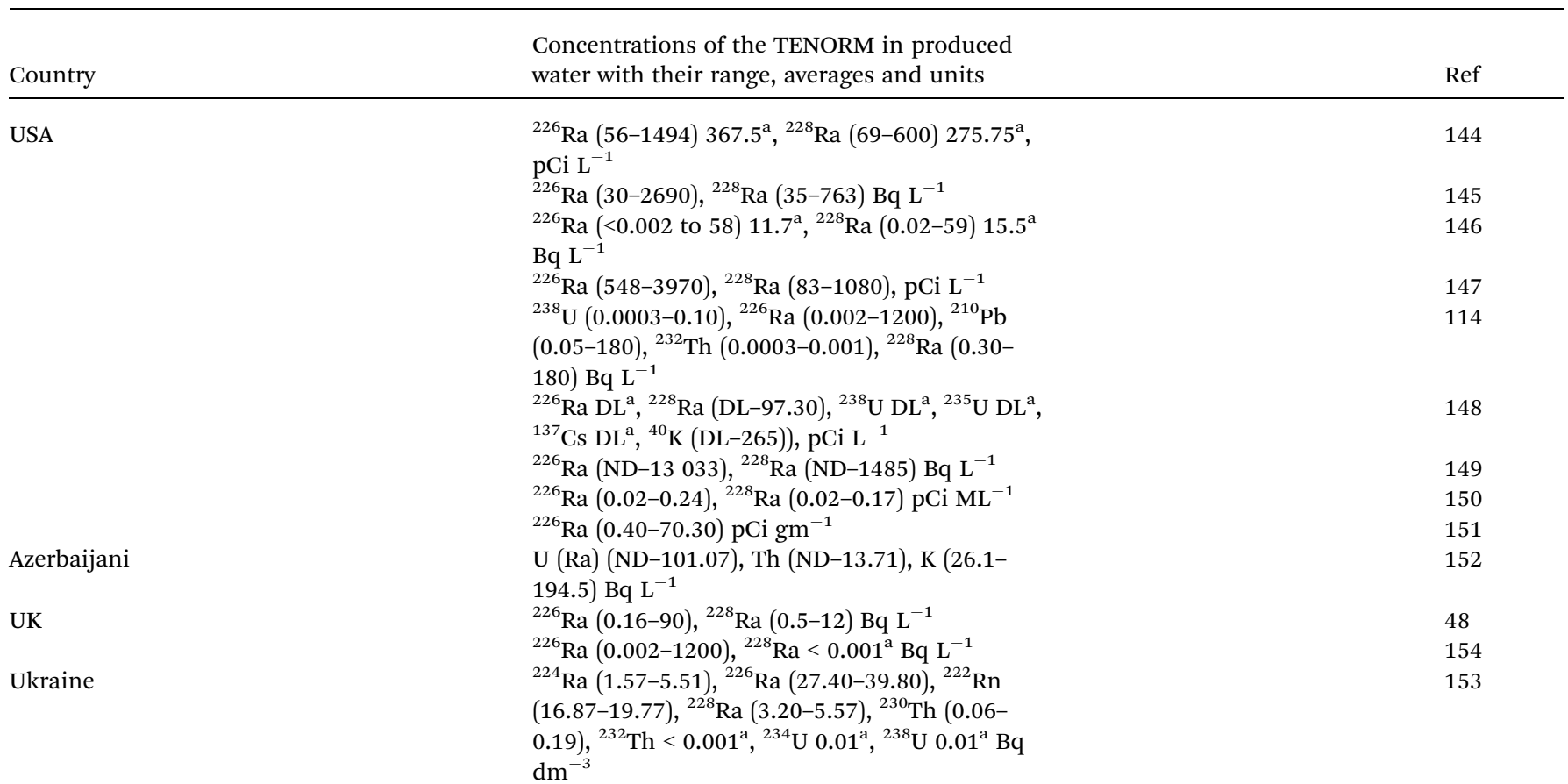

${ }^{a}$ ( ) the data between the brackets means the range $/{ }^{\mathrm{a}}$ is the averages of concentration/LD $=$ lower than the detection limits.

the region, which has high radioactivity. ${ }^{183,185}$ From safety risk assessment and management point of view, this is still a debatable matter, whereas, still if the likelihood is low then risk's consequences might be high taking in to account the volume of the oil \& gas industry's plants distributed around the world vs. number of routine maintenance jobs and people involved. Unfortunately, there are many industries that do not carry out survey or dose assessment. Routine maintenance of the facilities where the scales are generated should be carried out while considering the dose values to minimize the risk of contamination to the workers and the environment. In the case of scales containing carbonate, the tubes with hydrochloric acid should be efficiently washed. Meanwhile, the wet mechanical treatment should be used in the case of scales containing sulfates, and the workers must wear special respirators and anti-pollution clothing.

\subsection{Sludge}

Sludge is a viscous substance consisting of a complex mixture containing various amounts of waste mineral, waste oil, wastewater, sand, etc. ${ }^{92,184}$ This substance often contains silica compounds but may also exhibit substantial amounts of barium. ${ }^{83,155}$ Sludge from petroleum industries accumulates in crude oil and natural gas reservoirs, refineries, desalination plants, transport pipelines, and other places during the production processing and transportation of oil and natural gas. ${ }^{83,92,148,155}$ Such accumulated sludge from the petroleum industry is considered hazardous waste according to the regulations set forth by the Environmental Protection Law and
Hazardous Waste Handling Regulations. Radionuclides were reported in the scale and sludge found in machinery and equipment in the oil and gas fields in northern Germany by Kolb and Wojcik. However, some radioactive elements develop the ${ }^{238} \mathrm{U}$ and ${ }^{232} \mathrm{Th}$ series. ${ }^{22}$ Many researchers worldwide studied the radioactivity of the sludge produced in the oil and gas industry. Several radioactive elements, particularly the highly abundant and long-range Ra isotopes, such as ${ }^{226} \mathrm{Ra},{ }^{228} \mathrm{Ra}$, and ${ }^{224} \mathrm{Ra}$, and other radioactive nuclides, were reported in the natural decay of ${ }^{238} \mathrm{U}$ and ${ }^{232} \mathrm{Th}$ series and ${ }^{40} \mathrm{~K}$ element.

The survey included several studies on the sludge generated in the oil and gas industry in different parts of the world..$^{1,30,129,173,185}$ However, many sludge components are naturally dangerous. Thus, different types of wastes, including sludge of all types (chemical, biological, and oily sludge) and of particular environmental importance, are created during the treatment of crude oil. Risky wastes are generated in bulk at oil refineries worldwide and vary from one place to another. For example, petroleum facilities in India annually produce approximately 20000 tons of oily sludge. Meanwhile, the volume of sludge from oil and gas production in Australia is relatively small (approximately $200 \mathrm{~m}^{3}$ per year) compared with Europe and the USA. Sludge is disposed of in landfills or directly dumped into the sea from the production platform. The latest assessment by the $(\mathrm{EPA}, 2017)$ indicated that the average concentration of radionuclide of Ra in the sludge is $2.775 \mathrm{~Bq}$ $\mathrm{g}^{-1}$ or approximately $2775 \mathrm{~Bq} \mathrm{~kg}^{-1}$. The manner by which to safely dispose of such oily sludge is one of the major problems faced by oil refineries. To date, approximately 9 billion tons of 
Table 5 Shows the typical ranges or mean values of the TENORM in scales in the oil and gas industry in different regions of the world, including recent data ${ }^{a}$

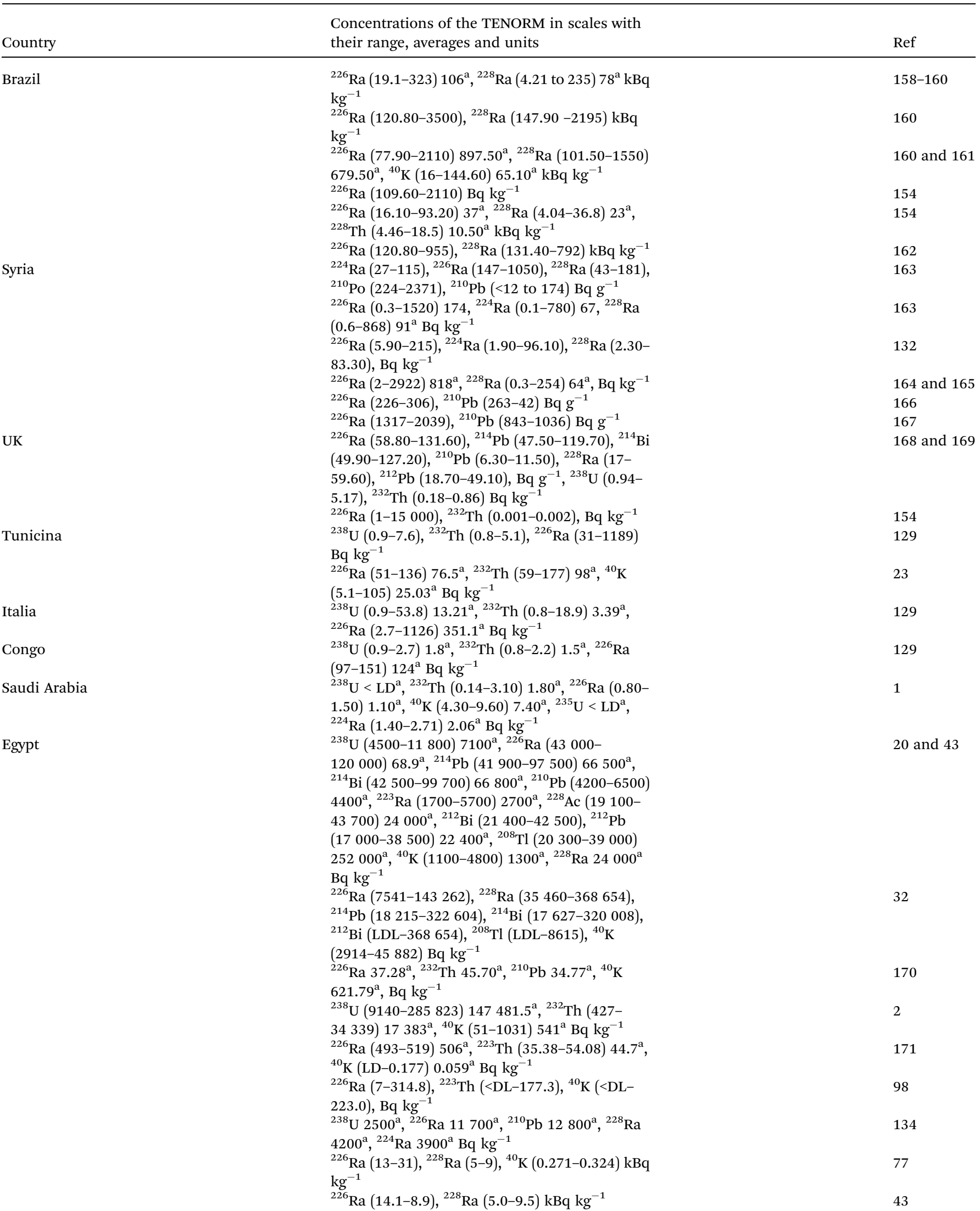


Table 5 (Contd.)

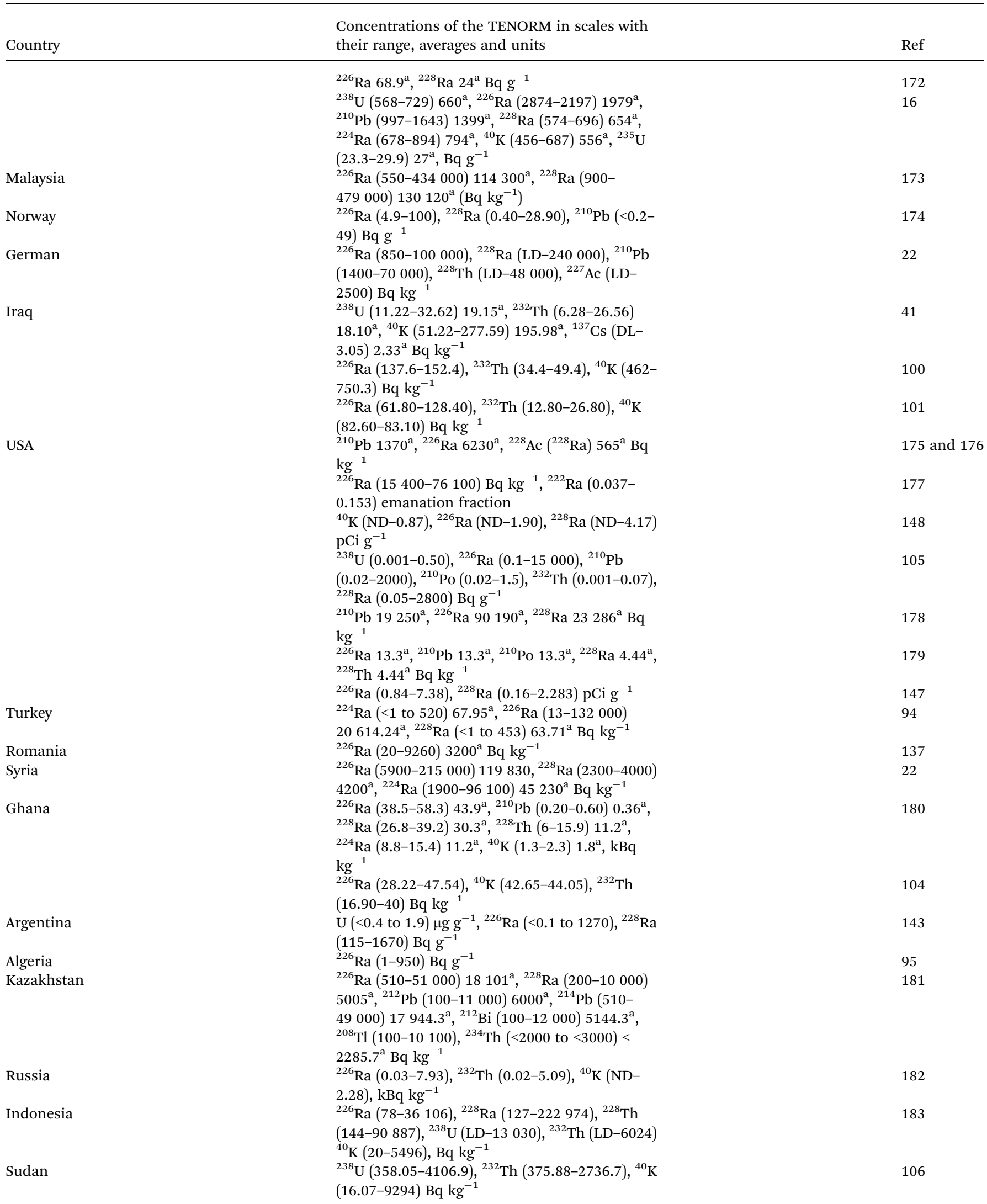

${ }^{a}$ ( ) the data between the brackets means the range/ ${ }^{\mathrm{a}}$ is the averages of concentration/LD = lower than the detection limits. 
Table 6 shows the typical ranges or mean values of TENORM in sludge in the oil and gas industry in different regions of the world, including recent data ${ }^{a}$

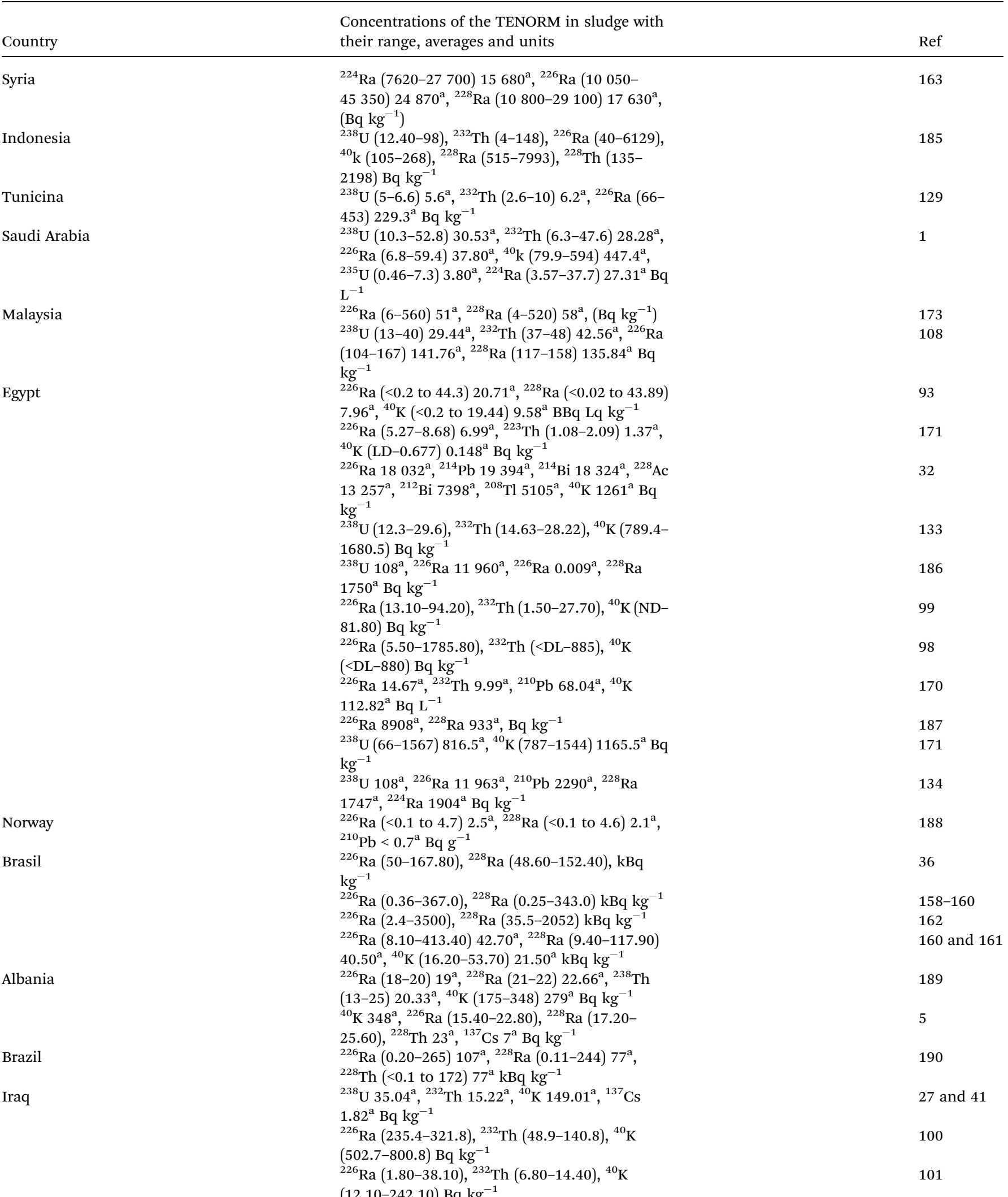

USA

${ }^{210} \mathrm{~Pb} 5148^{\mathrm{a}},{ }^{226} \mathrm{Ra} 59000^{\mathrm{a}},{ }^{228} \mathrm{Ac}\left({ }^{228} \mathrm{Ra}\right) 28501^{\mathrm{a}}$

175 and 176 $\mathrm{Bq} \mathrm{kg}{ }^{-1}$ 
Table 6 (Contd.)

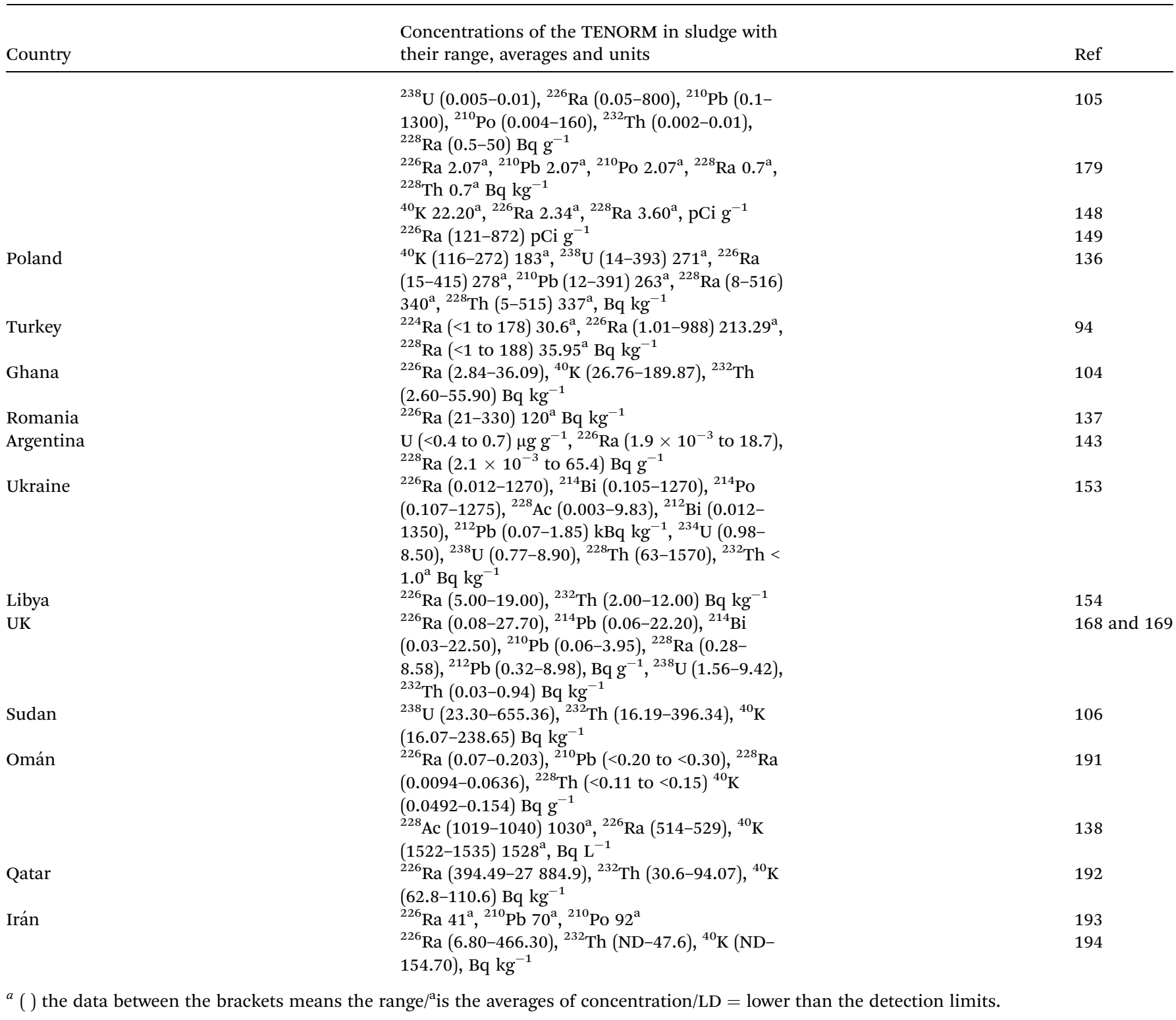

Table 7 Shows the range and mean values of TENORM in water samples found in the oil and gas industry and production facilities in different regions of the world, including recent data ${ }^{a}$

\begin{tabular}{|c|c|c|}
\hline Country & Concentrations of the TENORM in water samples with their range, averages and units & Ref \\
\hline Iraq & ${ }^{238} \mathrm{U}(2.41-43.18),{ }^{232} \mathrm{Th}(0.13-7.43) \mathrm{Bq} \mathrm{kg}{ }^{-1}$ & 197 \\
\hline Azerbaiyán & ${ }^{226} \mathrm{Ra}(\mathrm{ND}-101.70),{ }^{232} \mathrm{Th}(\mathrm{ND}-13.71),{ }^{40} \mathrm{~K}(26.10-194.50), \mathrm{Bq} \mathrm{L}^{-1}$ & 154 \\
\hline \multirow[t]{3}{*}{ USA } & ${ }^{226} \mathrm{Ra}(425-1840),{ }^{228} \mathrm{Ra}(616-1630)$ & 179 \\
\hline & ${ }^{210} \mathrm{~Pb} 815^{\mathrm{a}},{ }^{226} \mathrm{Ra} 1481^{\mathrm{a}},{ }^{228} \mathrm{Ac}\left({ }^{228} \mathrm{Ra}\right) 251^{\mathrm{a}} \mathrm{Bq} \mathrm{kg}{ }^{-1}$ & 175 and 176 \\
\hline & ${ }^{226} \mathrm{Ra}(0.15-120),{ }^{228} \mathrm{Ra}(\mathrm{ND}-17) \mathrm{Bq} \mathrm{L}{ }^{-1}$ & 199 \\
\hline Irán & ${ }^{232} \mathrm{Th}(8.7-403),{ }^{40} \mathrm{~K}(82-815){ }^{226} \mathrm{Ra}(0.1-30.3) \mathrm{Bq} \mathrm{L}^{-1}$ & 198 \\
\hline Nigeria & ${ }^{238} \mathrm{U}(2.9-13.65),{ }^{232} \mathrm{Th}(0.34-3.89),{ }^{40} \mathrm{~K}(48.39-109.39), \mathrm{Bq} \mathrm{L}^{-1}$ & 200 \\
\hline Tunicina & ${ }^{226} \mathrm{Ra} 0.037^{\mathrm{a}},{ }^{232} \mathrm{Th} 0.027^{\mathrm{a}},{ }^{40}{\mathrm{~K} 0.22^{\mathrm{a}} \mathrm{Bq} \mathrm{L}^{-1}}$ & 23 \\
\hline \multirow[t]{2}{*}{ Egypt } & ${ }^{226} \mathrm{Ra} 4.895^{\mathrm{a}},{ }^{232} \mathrm{Th} 2.247^{\mathrm{a}},{ }^{210} \mathrm{~Pb} 32.87^{\mathrm{a}},{ }^{40} \mathrm{~K} 31.852^{\mathrm{a}}, \mathrm{Bq} \mathrm{L} \mathrm{L}^{-1}$ & 170 \\
\hline & ${ }^{226} \mathrm{Ra}(5-40),{ }^{214} \mathrm{~Pb}(0.8-27),{ }^{214} \mathrm{Bi}(1.3-27),{ }^{228} \mathrm{Ac}(1.1-59),{ }^{212} \mathrm{Bi}(0.7-12),{ }^{208} \mathrm{Tl}(1.1-4),{ }^{40} \mathrm{~K}(19-29) \mathrm{Bq} \mathrm{L}{ }^{-1}$ & 32 \\
\hline Turkey & ${ }^{224} \mathrm{Ra}(<1$ to 4$),{ }^{226} \mathrm{Ra}(<3$ to 10$),{ }^{228} \mathrm{Ra}(<1$ to $<4) \mathrm{Bq} \mathrm{kg}^{-1}$ & 94 \\
\hline Romania & ${ }^{238} \mathrm{U}(0.043-18.5),{ }^{226} \mathrm{Ra}(1.8-45),{ }^{232} \mathrm{Th}(0.2-12.2),{ }^{40} \mathrm{~K}(25-899) \mathrm{mBq} \mathrm{L}{ }^{-1}$ & 137 \\
\hline
\end{tabular}

${ }^{a}$ ( ) the data between the brackets means the range/ ${ }^{\mathrm{a}}$ is the averages of concentration/LD $=$ lower than the detection limits. 
Table 8 Shows the range and mean values of TENORM in soil samples found in the oil and gas industry and production facilities in different regions of the world, including recent data ${ }^{a}$

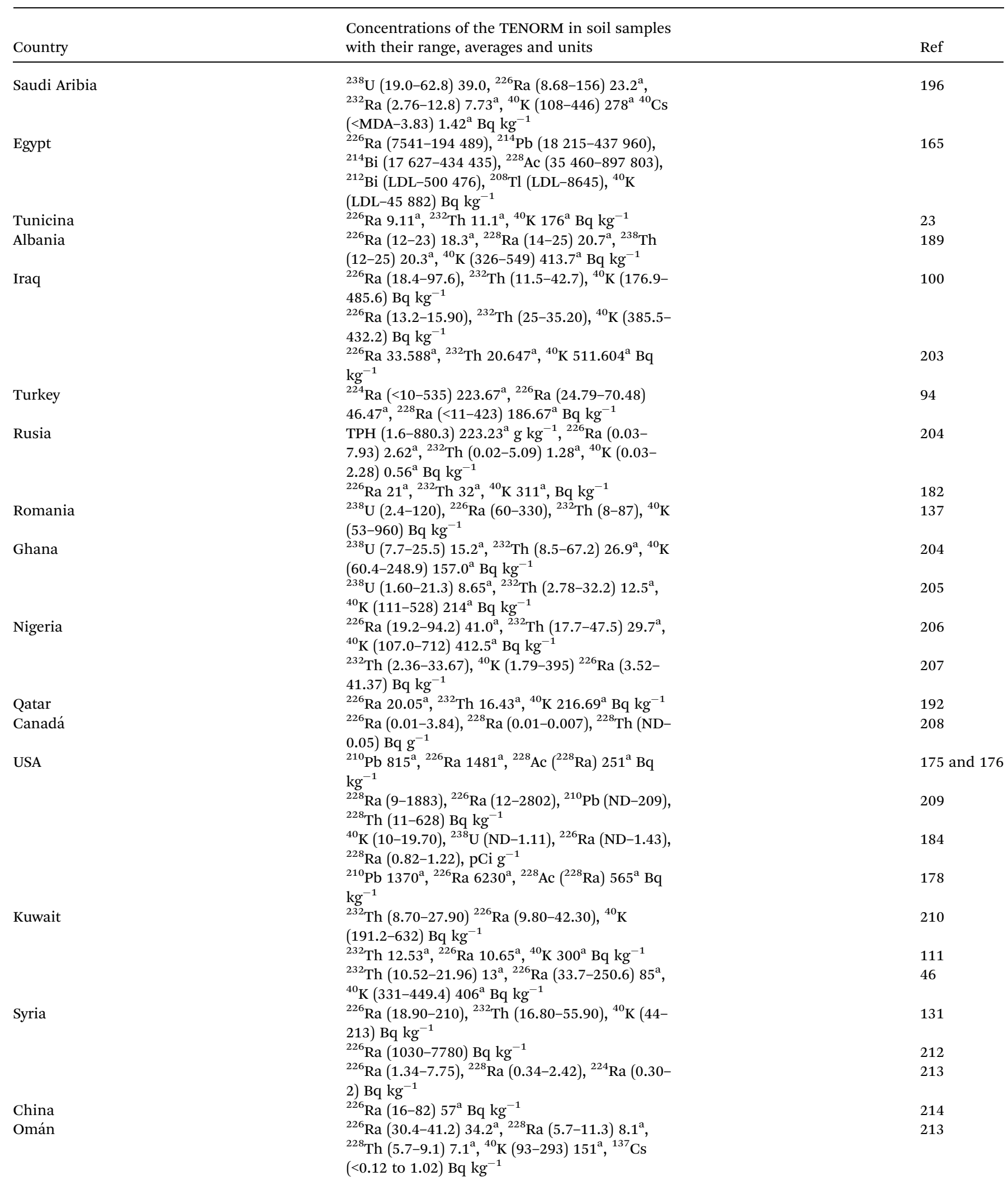

${ }^{a}$ ( ) the data between the brackets means the range/ ${ }^{\mathrm{a} i s}$ the averages of concentration/LD = lower than the detection limits. 
Table 9 Shows the range and mean values of TENORM in sand samples found in the oil and gas industry and production facilities in different regions of the world, including recent data ${ }^{a}$

\begin{tabular}{|c|c|c|}
\hline Egypt & $\begin{array}{l}{ }^{226} \mathrm{Ra} 3.4^{\mathrm{a}},{ }^{232} \mathrm{Th} 3.1^{\mathrm{a}},{ }^{40} \mathrm{~K} 37.8^{\mathrm{a}} \mathrm{Bq} \mathrm{kg}^{-1} \\
{ }^{226} \mathrm{Ra}(4.29-18.52) 11.63^{\mathrm{a}},{ }^{232} \mathrm{Th}(4.56-18.65) \\
11.41^{\mathrm{a}},{ }^{238} \mathrm{U}(5.31-17.46) 10.86^{\mathrm{a}},{ }^{40} \mathrm{~K}(145.85- \\
441.15) 327.65^{\mathrm{a}}, \mathrm{Bq} \mathrm{kg}^{-1}\end{array}$ & $\begin{array}{l}99 \\
47\end{array}$ \\
\hline Indonesia & $\begin{array}{l}{ }^{226} \mathrm{Ra}(4686-211310),{ }^{228} \mathrm{Ra}(7548-170430), \\
{ }^{228} \mathrm{Th}(4636-177 \mathrm{790}),{ }^{238} \mathrm{U}(\mathrm{LD}-4810),{ }^{232} \mathrm{Th} \\
(11.60-6493){ }^{40} \mathrm{~K}(297-4930), \mathrm{Bq} \mathrm{kg}^{-1}\end{array}$ & 183 \\
\hline Sudan & $\begin{array}{l}{ }^{238} \mathrm{U}(13.89-2807.36),{ }^{232} \mathrm{Th}(14.60-3466.24),{ }^{40} \mathrm{~K} \\
(16.6-196.28) \mathrm{Bq} \mathrm{kg}^{-1}\end{array}$ & 106 \\
\hline Sri Lanka & $\begin{array}{l}{ }^{40} \mathrm{~K}(0.338-0.514),{ }^{210} \mathrm{~Pb}(0.015-0.007),{ }^{232} \mathrm{Th} \\
(0.030-0.040),{ }^{226} \mathrm{Ra}(0.012-0.0145) \mathrm{Bq} \mathrm{g}^{-1}\end{array}$ & 215 and 216 \\
\hline Norway & $\begin{array}{l}{ }^{226} \mathrm{Ra}(<0.1 \text { to } 22) 4^{\mathrm{a}},{ }^{228} \mathrm{Ra}(<0.1-13) 2.5^{\mathrm{a}},{ }^{210} \mathrm{~Pb}< \\
0.5^{\mathrm{a}} \mathrm{Bqg}^{-1}\end{array}$ & 188 \\
\hline
\end{tabular}

oily sludge wastes are found on the planet. ${ }^{\mathbf{8 3 , 9 2 , 1 5 5 , 1 7 1 , 1 9 5}}$ This volume is increasing every minute and may vary from one place to another. Although the concentration of radiation is less in the sludge than in the standards, sludge is more soluble in the environment. Accordingly, sludge is formed with produced water, and is considered a form of petroleum wastes extremely hazardous to humans and the environment in case of overexposure..$^{35,83,92,169-195}$ Sludge is classified as hazardous waste because radium isotopes and their progenies are strong gamma emitters and other radioactive nuclides that emit beta and gamma such as ${ }^{210} \mathrm{~Pb}$, and also those emitting alpha such as ${ }^{210}$ Po. Therefore, the external radiation dose and associated risks in the vicinity of oil and gas facilities increases as sludge builds up. ${ }^{138,191}$ Sludge may be classified as hazardous wastes (more than the solid wastes) because it is often in liquid form, so when disposed of, it always seeps through the soil and gradually pollutes groundwater and shallow groundwater.

\section{TENORM in non-oil samples from oil industry fields and facilities}

Many researchers studied TENORM in non-oil samples, such as soil, sand, water, and plants. These samples were selected from the surrounding environments of the oil and gas industry. Thus, appropriate treatments in the cases with indicators of possible future hazards must be used to identify the long-term effect of radiation from the oil and gas industry and determine the extent to which the TENORM moves from oil and gas products and residues onto the surrounding environments. These researchers studied the effect of TENORM on workers, the public, and the environment. Many researchers were quick to take samples of the environment surrounding oil and gas facilities that are likely to be contaminated with TENORM. Then, these samples were studied, after which the transmission of radionuclides from the oil and gas industry was measured to avoid their effects on health and the environment.

Concentrations of the highly radioactive elements in these samples in an oil-contaminated environment are relatively high compared with the non-oil ones. For example, concentrations of radioactive elements obtained from soil samples in Saudi Arabia taken from the Ras Tanura area (an oil polluted environment) ${ }^{\mathbf{1 9 6}}$ are greater than those of the same radioactive elements obtained in sand samples taken from Qassim area in Saudi Arabia (an environment that is non-polluted by oil). ${ }^{224}$ This finding indicates that the oil spill may adversely affect the environment in which it has been extracted. In general, the concentrations of radionuclide activity in soil, water, plants, drill cutting, and other samples taken from oil industry fields and facilities (Tables 7-11) are higher than those obtained for

Table 10 Shows the range and mean values of TENORM in drill cutting samples found in the oil and gas industry and production facilities in different regions of the world, including recent data ${ }^{a}$

\begin{tabular}{|c|c|c|}
\hline Country & $\begin{array}{l}\text { Concentrations of the TENORM in Drill cutting } \\
\text { samples with their range, averages and units }\end{array}$ & Ref \\
\hline \multirow[t]{2}{*}{ USA } & ${ }^{226} \mathrm{Ra}(0.835-7.38),{ }^{228} \mathrm{Ra}(0.161-2.283) \mathrm{pCi} \mathrm{g}^{-1}$ & 147 \\
\hline & $\begin{array}{l}{ }^{208} \mathrm{Tl}(0.21-0.49),{ }^{226} \mathrm{Ra}(0.83-2.25),{ }^{228} \mathrm{Ra}(0.63- \\
1.63),{ }^{234} \mathrm{U}(0.34-1.94),{ }^{235} \mathrm{U}(0.010-0.123),{ }^{238} \mathrm{U} \\
(0.46-2.09),{ }^{228} \mathrm{Th}(0.51-2.12),{ }^{230} \mathrm{Th}(0.54-3.03) \\
{ }^{232} \mathrm{Th}(0.64-2.17) \mathrm{pCi} \mathrm{g}{ }^{-1}\end{array}$ & 217 \\
\hline \multirow[t]{3}{*}{ Poland } & ${ }^{40} \mathrm{~K}(680-999),{ }^{232} \mathrm{Th}(23.30-31) \mathrm{Bq} \mathrm{kg}^{-1}$ & 218 \\
\hline & $\begin{array}{l}{ }^{40} \mathrm{~K}(446-1092) 815^{\mathrm{a}},{ }^{238} \mathrm{U}(35-99) 57^{\mathrm{a}},{ }^{226} \mathrm{Ra}(29- \\
120) 62^{\mathrm{a}},{ }^{210} \mathrm{~Pb}(30-43) 69^{\mathrm{a}},{ }^{228} \mathrm{Ra}(22-47) 37^{\mathrm{a}}, \\
{ }^{228} \mathrm{Th}(19-47) 37^{\mathrm{a}}, \mathrm{Bq} \mathrm{kg}{ }^{-1}\end{array}$ & 136 \\
\hline & $\begin{array}{l}{ }^{40} \mathrm{~K}(289-3590) 966^{\mathrm{a}},{ }^{238} \mathrm{U}(35-46) 37^{\mathrm{a}},{ }^{226} \mathrm{Ra}(15- \\
44) 25^{\mathrm{a}},{ }^{210} \mathrm{~Pb}(15-54) 30^{\mathrm{a}},{ }^{228} \mathrm{Ra}(13-31) 20^{\mathrm{a}}, \\
{ }^{228} \mathrm{Th}(13-26) 18^{\mathrm{a}}, \mathrm{Bq} \mathrm{kg}^{-1}\end{array}$ & 136 \\
\hline
\end{tabular}

${ }^{a}$ () the data between the brackets means the range/ ${ }^{a}$ is the averages of concentration/LD $=$ lower than the detection limits. 
Table 11 Shows the range and mean values of TENORM in other environmental samples found in the oil and gas industry and production facilities in different regions of the world, including recent data ${ }^{a}$

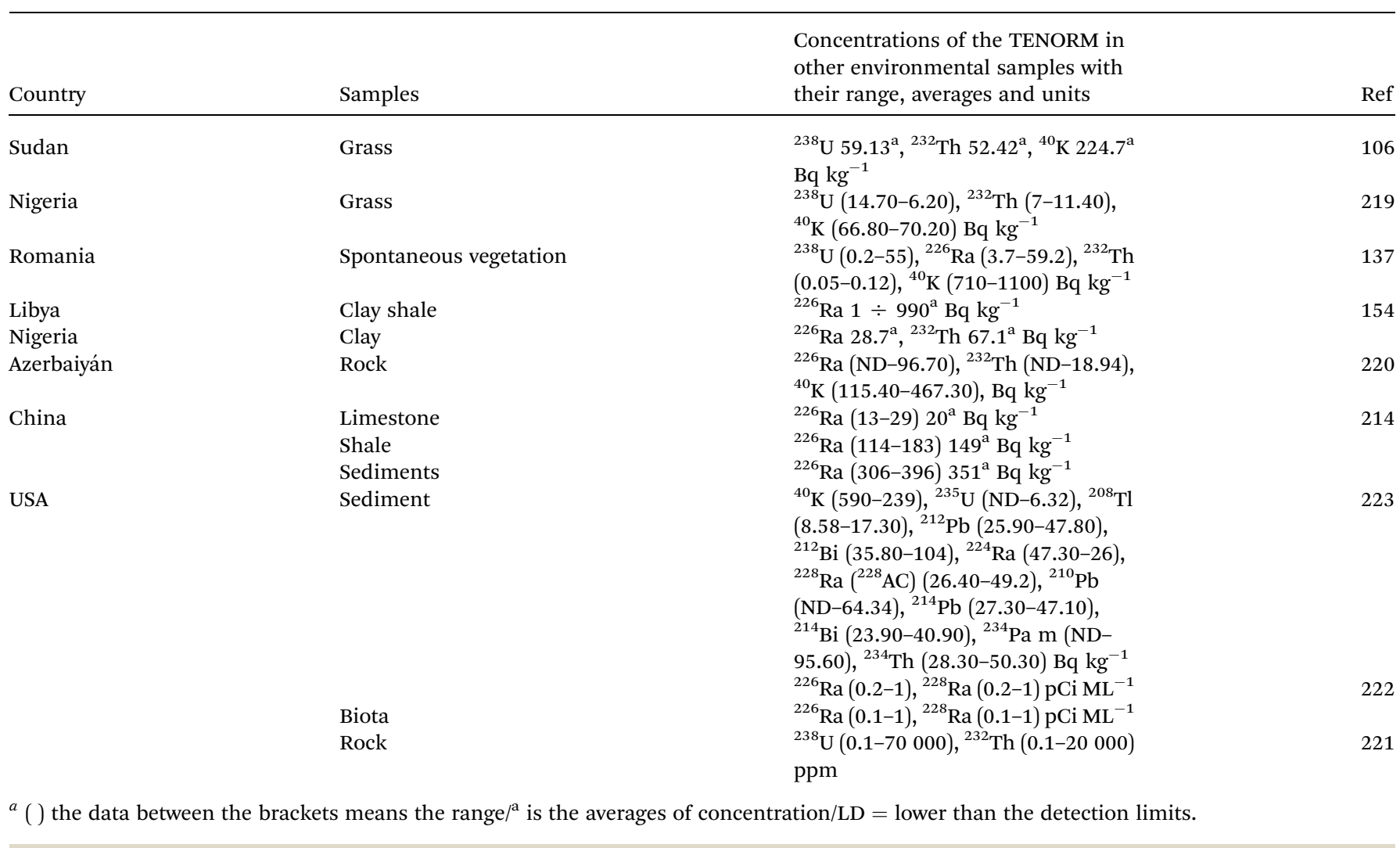

the same samples in non-polluted environments. For example, concentrations of radioactive elements of soil samples for the oil-bearing environment ${ }^{225}$ are higher than for soil samples of the non-oil-bearing environment. ${ }^{226}$ The results of an investigation done on samples in the oil environment in Kuwait ${ }^{46}$ indicates that the discharge of produced water has an effect on the concentrations of TENORM in the environment of the lake of the produced water, thereby increasing their value compared with the values previously reported through the broader Kuwaiti environment. High concentrations of activity may be the result of oil spillage, uncontrolled storage or unsafe discharge, leakage of sludge, produced water or scales, and their interaction with the environmental components.

\section{Risks of TENORMs on the environment}

The principle of environmental protection of radiation applies extensively to the nuclear industry, but in the oil and gas industry, this protection seems to be relatively low. Radiation protection is unconstrained to animals or plants, while humans are protected by certain radiological standards. ${ }^{227,228}$ For this reason, the International Commission on Radiological Protection (ICRP, 1991) postulated the adoption of human protection standards as criteria for the protection of living organisms. $^{227-229,278}$ This condition indicates that if the overall exposure to radiation from TENORM discharges, or the disposal of TENORM wastes is less than the general limit of $1 \mathrm{mSv} \mathrm{y}^{-1}$, then the radioactive doses received by organisms are considered acceptable. ${ }^{228}$ But it should take into account that it is still associated with high uncertainties. Using contaminated TENORM or waste media and their improper handling, storing, and transfer without effective control can contaminate multiple land areas in the surrounding environment which, in turn, can lead to the potential exposure of the public. ${ }^{82,133,227-230}$ The environmental effects of the TENORM resulting from the industry of oil and gas can be summarized as follows: (1) discharge of produced water, scale, and sludge into the offshore facilities of the oil and gas industry may lead to the transfer of TENORM to the surrounding environment. Accordingly, the content of radionuclides in rock and soil deposits, river water, and other components of the surrounding environment increases, which may be a cause of potential contamination of drinking water. These radionuclides may be transported through water and soil to the animals and plants. (2) The petroleum industry has a low TENORM activity and a low generation rate in the environment. ${ }^{230-232}$ For this reason, it may be unlikely that radioactive exposures and radiation impact on life are significant because of the discharge of small amounts of petroleum wastes, but these wastes accumulate over time, and thus may pose radioactive hazards to humans and their environment. 


\subsection{The main forms of petroleum pollution TENORMs}

Disposal of hazardous waste from petroleum industries by burying them in the ground or dumping them into the sea leads to the possibility of pollution of air, soil, groundwater, surface and sea water, which leads to possible adverse effects on the environment, animals, plants and fish, and thus on the health of man himself. ${ }^{230-240}$ Perhaps the most prominent of these forms are:

Impact on water. ${ }^{236-241}$ The extractive oil industry is highly influential in water as it is reflected in groundwater, surface water, rivers, oceans and seas, as a result of the waste generated from the exploration and extraction (drilling fluids and waste water), as well as extraction of oil through water injection in order to increase the withdrawal of oil and improve productivity. ${ }^{242}$ In this way, the water works to remove oil from the porous medium through the separation processes, which keeps oil in the reservoir.

Impact on groundwater. ${ }^{238-243}$ Groundwater is polluted as a result of waste liquid and non-liquid drilling (basins Waste). These wastes contain high levels of salts such as barium, benzene, etc. ${ }^{\mathbf{2 4 4}}$ which are rich in radionuclides, where the liquid part of the waste is filtered to the ground water, causing serious radioactive contamination. ${ }^{232,245-248}$

Impact on surface water. ${ }^{8,138,225,249}$ All effluents from the oil and gas industry such as produced water, washing water for rigs, drilling machines, maintenance and repair, oil grease contaminated water, liquid sludge, etc., may contain radioactive materials. Consequently, discharging into the environment and lead to the release of these materials into the surface of the earth and may cause unexpected damage due to increase the concentrations of radioactive materials by leakage to subsurface water.

Effect on air. ${ }^{249-252}$ Air pollution caused by the emission of gas associated with the drilling and extraction, resulting mainly from the combustion of fuel and the process of disposal of unwanted gases that appear with oil extracted and the evaporation of volatile parts of oil spread over the surface of water. ${ }^{253-255}{ }^{222} \mathrm{Rn}$ is one of the most important gases emitted from the exploration and extraction processes.

Impact on soil. ${ }^{211,236-238,254-261}$ It is known that the drilling process directly affects the soil because it causes large impacts in the ground, and the drilling machines may cause leaking the fuel through the pores of the soil, as well as the oil residues. $^{242,258-261}$ Then, radionuclides are transferred to the soil and then to the plants and living cells. Existing methods for the disposal of radioactive petroleum wastes used by the oil and gas industry e.g. land farms, deep injection... etc. as well implementation of enhanced oil recovery technologies such produced water injection method that contains TENORM or hydraulic fracturing methods that use TENORM slurry, all also have a great impact to contaminate soil. The main forms of petroleum pollution TENORMs can be summarized in Fig. 3 as shown below:

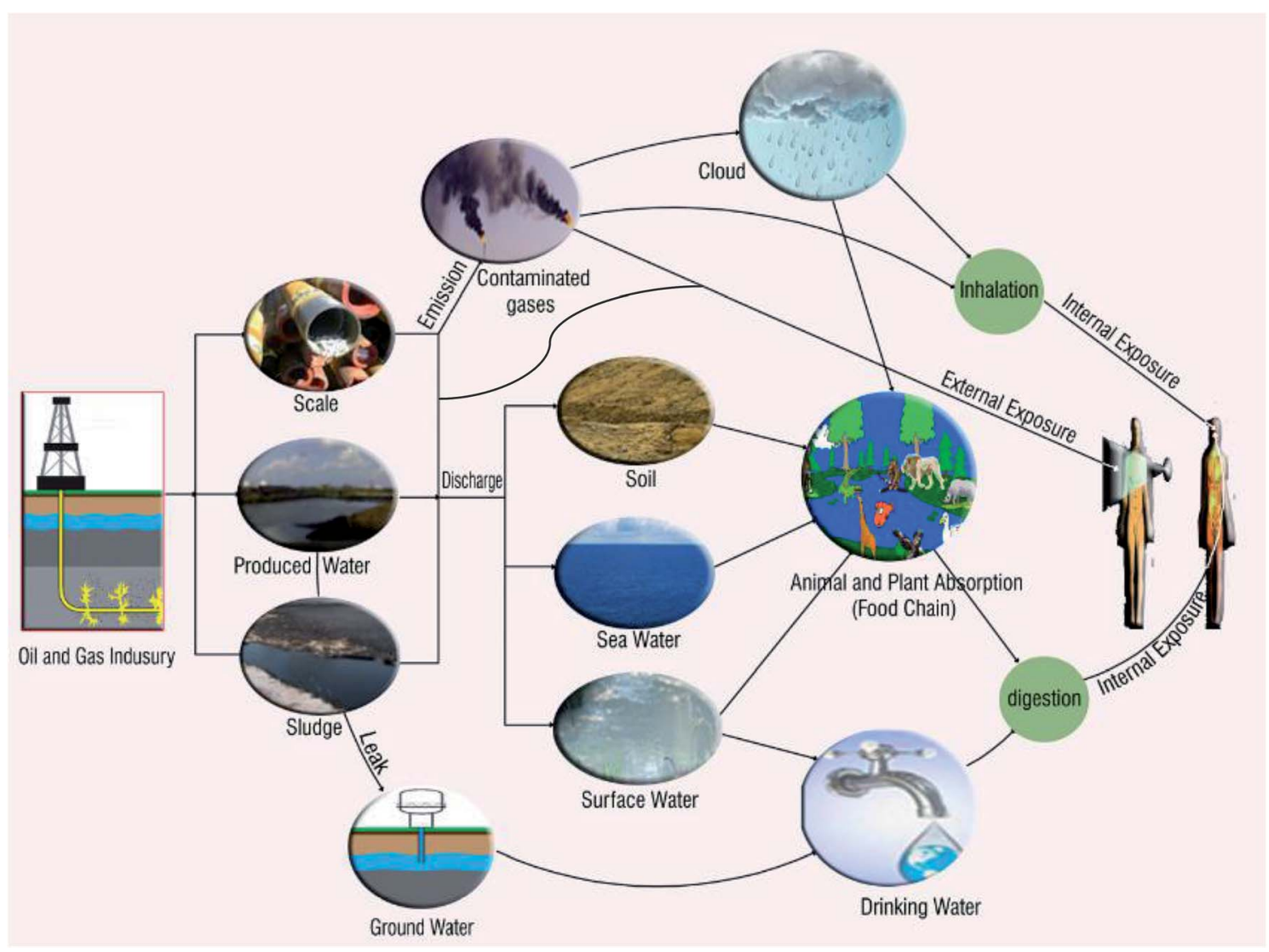

Fig. 3 The main forms of petroleum pollution of TENORMs. ${ }^{242,261}$ 
Water and soil contamination with oil containing radionuclides has effects on plants and organisms (birds, cattle, reptiles, etc.). ${ }^{262-265}$ Thus, these radionuclides may pass through the food chain to humans, causing many health effects such as cancer and others.

\section{Risks of TENORMs on human health}

Oil and gas products and residues may contain TENORMs, which then emit alpha, beta, and gamma radiation. Thus, TENORMs can be a source of radiation. A person can be exposed to TENORMs in two ways: external and internal exposures (see Fig. 3).

\subsection{External exposure (irradiation)}

In this case, the source remains outside the body. Workers are exposed to gamma radiation during routine operations. The external gamma radiation passes through the steel walls of the tubes and vessels, and the dose rate on the surface of oil production pipelines and vessels can be within the tens of microSievert per hour. During closure and maintenance periods, workers may also be exposed to inhaled radon, a dust of the TENORM and gamma radiation. Studies, such as, , $33,39,42,139,171,202^{2}$ on oil and gas found that the rate of external radiation dose within the separators in the machinery and equipment is higher than that in the outer walls because the external gamma radiation inside the separator is unprotected by its steel walls.

\subsection{Internal exposure (contamination)}

The radioactive material is transported to the body either by inhalation, ingestion, or absorption. ${ }^{82,100,133,226-229}$ The radium equivalent activity in the sulfate scale may be greater than 500 $\mathrm{Bq} \mathrm{g}^{-1}$. Thus, only $100 \mathrm{mg}$ of inhaled dust is sufficient for an irradiation dose exceeding the annual general dose limit of 1 mSv. Although the amount of radon released is low, concentrations of radon in non-aerated vats of scale, sludge, and sand can cause increased exposure to radiation.

Many researchers and specialists addressed the health effects of ionizing radiation exposure. The results showed that the health effects associated with exposure to ionizing radiation vary depending on the total amount of energy absorbed, time period, dose rate, and body exposed to radiation. A key consideration in dealing with TENORM is that, exposures are generally low and below the internationally defined regulatory levels. ${ }^{228}$ Exposure to TENORM produces no sharp and severe effects similar to the effects associated with exposure for high levels of radiation from man-made sources. In most cases, exposure to low ionizing radiation exhibits no adverse health effects. However, many new epidemiological and laboratory studies have concluded that exposure to low doses of ionizing radiation may still cause a risk..$^{230-233}$ A variety of cancers, including leukemia, lung cancer, stomach, esophagus, bone, thyroid, brain, and nervous system, have been associated with exposure to ionizing radiation. This indicates that exposure to TENORM over the limits of exposure to the general public or following inadequate safety precautions usually presents delayed effects, such as the development of some forms of cancer. Potential health effects are strongly linked to dose, and radiation exposure is unassociated with all forms of cancer. ${ }^{117,228,229}$ In general, many researchers have studied the risks of exposure to radiation from the oil and gas industry in different parts of the world. The handling and storage of contaminated petroleum waste by TNORMs can expose workers, public, and environment to harmful radiation doses. Meanwhile, burial and spread of petroleum wastes in the ground are associated with potential exposure to external radiation and inhalation of radon. If the concentrations of ${ }^{228} \mathrm{Ra}$, ${ }^{226} \mathrm{Ra}$, and ${ }^{40} \mathrm{~K}$ and the rest of the radioisotopes deposited in the scale, sludge, produced water, and other samples are determined, exposure can be measured through the highly common radiation indicators to assess the real doses of radiation, including the radon equivalent $\left(\mathrm{Ra}_{\mathrm{eq}}\right)$, dose-absorbed dose $\left(D_{\gamma \mathrm{r}}\right)$, and effective annual dose rate $\left(D_{\text {eff }}\right)^{42,82,169,187}$ These aforementioned factors are indicators of reference doses in the outer air at the height of $1 \mathrm{~m}$ above the Earth's surface and can be calculated from the equations adopted by the United Nations Scientific Committee on the effects of atomic radiation:

$$
\begin{gathered}
\mathrm{Ra}_{\mathrm{eq}}=C_{\mathrm{Ra}}+1.43 C_{\mathrm{Th}}+0.077 C_{\mathrm{K}} \\
D_{\gamma}=\left(0.462 C_{\mathrm{Ra}}+0.604 C_{\mathrm{Th}}+0.0417 C_{\mathrm{K}}\right) \times 10^{-3} \\
D_{\text {eff }}=D_{\gamma} \times 10^{-6} \times 8760 \times 0.20 \times 0.7
\end{gathered}
$$

where $\mathrm{Ra}_{\text {eq }}$ is radium equivalent activity measured by $\mathrm{Bq} \mathrm{kg}^{-1}$, and it is a radiation index used to evaluate actual radioactivity in substances containing natural radionuclides; $C_{\mathrm{Ra}}, C_{\mathrm{Th}}$, and $C_{\mathrm{K}}$ are the activities for ${ }^{226} \mathrm{Ra},{ }^{228} \mathrm{Ra}$, and ${ }^{40} \mathrm{~K}$, respectively; $D_{\gamma \mathrm{r}}$ is the rate of dose resulting from gamma rays measured by $\left(\mathrm{nGy} \mathrm{h}^{-1}\right)$; and $D_{\text {eff }}$ is the annual effective dose and measured by $\mathrm{mSv}^{-1}$. Several studies have attempted to measure the radioactivity doses and the true dangers in the petroleum industry. Some survey results are presented in Table 6 .

These results provide evidence that the oil and gas production areas may be contaminated with TENORM but generally low. But over time, the accumulation of oil and gas residues under improper management can produce harmful radiation doses to humans and the environment..$^{23,39,95,104}$ The higher the level of radioactivity in waste, the greater the radiation effects, especially when considering the possibility of exposure to operators through internal pollution by absorbing dust during waste treatment. ${ }^{94,139,198,201,266}$ Immediacy to the source of radiation exhibits a significant part in the radioactivity effect. This condition may lead to the accumulation of additional radiation exceeding the limits allowed to the public, thereby leading to health risks in these communities (Table 12).

Overall, when comparing studies done to measure TENORMs in the oil and gas industries with global liquid fuel production per day, we find that there are large amounts of waste likely to contain radioactive materials, which are traditionally disposed of in the environment. ${ }^{267,268}$ All onshore and offshore drilling activities are extremely risky and have a serious potential to harm people, cause environmental damage or loss of assets, and negatively impact industry reputation. For this 
Table 12 Radiation risk indicators in some oil industries

\begin{tabular}{|c|c|c|c|c|}
\hline Country & $\mathrm{Ra}_{\mathrm{eq}}\left(\mathrm{Bq} \mathrm{kg}^{-1}\right)$ & $D_{\gamma \mathrm{r}}\left(\mathrm{nGy} \mathrm{h}^{-1}\right)$ & $D_{\text {eff }}\left(\mathrm{mSv} \mathrm{y}^{-1}\right)$ & Ref \\
\hline \multirow[t]{2}{*}{ Saudi Arabia } & $(21.6-204) 62.1$ & (10.5-96.4) 29.3 & $(0.013-0.118) 0.038$ & 196 \\
\hline & $1.35-173$ & $<\mathrm{LD}-83.6$ & & 1 \\
\hline & $(544-596) 570 \times 10^{3}$ & $(250-273) 262$ & $(306-335) 321$ & 171 \\
\hline Tunisian & $0.09-398$ & $0.043-177$ & $5.28 \times 10^{-5}$ to $3.64 \times 10^{-4}$ & 23 \\
\hline Algeria & & $(0.1-100) \times 10^{3}$ & $(0.01-0.60)$ & 95 \\
\hline Congo, Italy & & $(0.1-6) \times 10^{3}$ & & 129 \\
\hline Turkey & & $(0.2-25.7) \times 10^{3}$ & & 94 \\
\hline \multirow[t]{2}{*}{ Ghana } & & $(10.0-57.0)$ & $(12.6-83.4)$ & 139 \\
\hline & (10.01-128.92) & & & 104 \\
\hline \multirow[t]{2}{*}{ Nigeria } & & $(21-117.5) 54.6 \times 10^{3}$ & $(0.03-0.2) 0.07$ & 200 \\
\hline & $(51.04-100.85) 74.71$ & $(23-47) 35$ & $(0.027-0.057) 0.043$ & 201 \\
\hline \multirow{2}{*}{ Iraq } & & $(0.08-11.2)$ & & 100 \\
\hline & (5.21-79.84) 47.39 & (2.49-37.53) 22.18 & $(0.012-0.184) 0.109$ & 39 \\
\hline USA & & & $(0.002-0.50)$ & 68 \\
\hline
\end{tabular}

reason, many researchers have taken the initiative to find safe ways to get rid of the tumor in the oil and gas industries. For example, Khalid Al Nabhani and others introduced a program to develop a larger TENORM risks management system in the oil and gas industries. ${ }^{269,270}$ This system emphasizes the importance of new methods of special personnel protective equipment protected by an effective and lightweight layer of lead-based materials, and introduces a new thermal chemical conversion technology (TCT) for the treatment of TENORM. ${ }^{270}$ This technology is designed to manage TENORM waste and ultimately turn it into renewable fuel and energy. ${ }^{19,271}$ This system also revealed that there is a strong correlation between the radioactive materials and presence of hydrocarbons, which identified knowledge and technical gaps related to TENORM in oil and gas production, and also rethink the interpretation of the theory of oil and gas formation based on logical scientific explanations. ${ }^{272}$ This system provides an analysis of risk assessment methods commonly used in the oil and gas industry and TENORM waste disposal options. ${ }^{273}$ To evaluate its effectiveness, the system uses a fate model, exposure paths, and integrated exposure pathways. ${ }^{272,273}$ It also examines reasonable scenarios in which pollutants can travel through the biosphere and atmosphere, reaching the humans, animals and environment. The real state scenario of TENORM wastes disposed of in the evaporation pond was simulated using RESRAD (version 6.5)..$^{274,275}$ The system also introduces a new approach to dynamic modeling and quantitative risks assessment of TENORMs exposure in the oil and gas industries by use the SMART approach, which integrates the rationality theory (SMART approach) and SHIPP methodology (system risk identification, prediction and prevention). The SHIPP methodology is a general framework used to model, identify and evaluate potential TENORM occupational exposure incidents. ${ }^{276,277}$ They focused on the relationship between legislation and policy in the oil and gas industry and laws related to the oil and gas industry that protect human health and environmental safety. Also highlighted the importance and activation of the role of public participation in drafting legislation that strives to balance the interests of the authorities with those of the public in a democracy. In spite of all the above, we find a big gap between the results of studies and scientific and technological research, which was concerned with the study and evaluation of risks related to the tumor in the oil and gas industry and how to safely dispose of it and the practice in the production facilities of the oil and gas industry. This requires that oil and gas production companies to adopt safer policies and turn the results of the studies into practice on the ground.

\section{Conclusions}

The review results of obtainable data relating to the incidence of TENORM in the oil and gas industry indicate that an initial conclusion can be strained on the necessity for further study in this field. Human and technological activities in the oil and gas industry can increase concentrations of naturally occurring radionuclides (TENORMs). An overall review was conducted to determine the concentrations of radioactive elements in petroleum products, petroleum residues (produced water, scales, and sludge) and in samples of oil environments (soil, water, and plant). The subsequent radioactive effects of the oil and gas industry on workers, public, and environment were also assessed. The activities of the observed elements showed varying ranges, as presented in the abovementioned tables. Evidently, the activities of some radionuclides exceed the $10 \mathrm{~Bq} \mathrm{~kg}^{-1}$ exemption level recommended in the safety standards of IAEA. This finding indicates that extended constant consideration and monitoring are required through most routine processes in the industry, because TENORM waste from the oil and gas industry may 
produce high levels of radiation exposure. These exposures are generally caused by external $\gamma$-radiation that comes from the radionuclides and their offspring, which in turn, may lead to multiple environmental and health risks.

\section{Conflicts of interest}

The authors have no affiliation with any organization with a direct or indirect financial interest in the subject matter discussed in the manuscript.

\section{Acknowledgements}

This paper is funded by the International Exchange Program of Harbin Engineering University, China Scholarship Council (CSC) for Innovation-oriented Talents Cultivation.

\section{References}

1 F. S. Al-Saleh and G. A. Al-Harshan, Measurements of radiation level in petroleum products and wastes in Riyadh City Refinery, J. Environ. Radioact., 2008, 99(7), 1026-1031.

2 N. Mansour, T. S. Ahmed, M. Fayez-Hassan, N. Hassan, M. Gomaa and A. Ali, Measurements of Radiation Level around the Location of NORM in Solid Wastes at Petroleum Companies in Egypt, Journal of American Science, 2012, 8(6), 252-260.

3 S. I. Rabie and N. M. Authority, Significance of Airborne Gamma-Ray Spectrometric Data of Umm Bisilla Area, Central Eastern Desert Egypt, in Second Arab Conference on the Peaceful Uses of Atomic Energy, 1995, pp. 283-305.

4 K. P. Maphoto, Determination of natural radioactivity concentrations in soil: a comparative study of Windows and Full Spectrum Analysis, University of the Western Cape, 2004.

5 G. Xhixha et al., Assessment of Naturally Occurring Radioactive Materials (NORMs) in soils from the Kuçova oilfield, Albania, Conference: Proceedings of the 7th International Conference on Environmental and Geological Science and Engineering (EG '14), Salerno, Italy, 2014, pp. 154-160.

6 P. Evans, G. Jonkers, E.-M. Steffan, J. Campbell, and C. Lloret, Guidelines for the Management of Naturally Occurring Radioactive Material (NORM) in the Oil and Gas Industry, Conference: SPE International Conference and Exhibition on Health, Safety, Security, Environment, and Social Responsibility, 2016.

7 P. Mahawatte and K. N. R. Fernando, Radioactivity levels in beach sand from the West Coast of Sri Lanka, J. Natl. Sci. Found. Sri Lanka, 2013, 41(4), 279-285.

8 B. Bangunan, Radiological studies of naturally occurring radioactive materials in some Malaysia's sand used in building construction, Malaysian J. Anal. Sci., 2009, 13(1), 29-35.

9 A. S. Paschoa, Naturally occurring radioactive materials (NORM) and petroleum origin, Appl. Radiat. Isot., 1997, 48(10), 1391-1396.
10 D. L. Blunt, D. Elcock, K. P. Smith, D. Tomasko, and J. A. Viel, Disposal of NORM-Contaminated Oil Field Wastes in Salt Caverns, Argonne National Laboratory (Argonne), Office of Fossil Energy, the US Department of Energy (DOE), 1995.

11 E. M. El Afifi, et al., Treatment of TENORM waste: phosphogypsum produced in fertilizer industry, Radiochemistry, 2010, 52(4), 441-445.

$12 \mathrm{H}$. El-Didamony, et al., Radiological characterization and treatment of contaminated phosphogypsum waste, Radiochemistry, 2013, 55(4), 454-459.

13 E. M. El Afifi, et al., Characterization of phosphogypsum wastes associated with phosphoric acid and fertilizers production, J. Environ. Radioact., 2009, 100(5), 407-412.

14 M. F. Attallah, et al., Environmental impact assessment of phosphate fertilizers and phosphogypsum waste: elemental and radiological effects, Microchem. J., 2019, 146, 789-797.

15 M. F. Attallah and A. M. Abdel-Monem, Estimation of environmental impacts of NORM from some raw materials used in ceramic industry, Radiochemistry, 2014, 56(3), 332-338.

16 H. M. Abdelbary, E. A. Elsofany, Y. T. Mohamed, M. M. AboAly and M. F. Attallah, Characterization and radiological impacts assessment of scale TENORM waste produced from oil and natural gas production in Egypt, Environ. Sci. Pollut. Res., 2019, 1-11, DOI: 10.1007/s11356-019-06183-x.

17 M. F. Attallah, M. A. Hilal and S. I. Moussa, Quantification of some elements of nuclear and industrial interest from zircon mineral using neutron activation analysis and passive gamma-ray spectroscopy, Appl. Radiat. Isot., 2017, 128, 224-230.

18 J. A. Veil, K. P. Smith, D. Tomasko, D. Elcock, D. Blunt and G. P. Williams, Disposal of NORM Waste in Salt Caverns, SPE International Conference on Health, Safety, and Environment in Oil and Gas Exploration and Production, Society of Petroleum Engineers, Caracas, Venezuela, 1998, p. 8.

19 K. Al Nabhani, F. Khan and M. Yang, Technologically Enhanced Naturally Occurring Radioactive Materials in oil and gas production: a silent killer, Process Saf. Environ. Prot., 2016, 99, 237-247.

20 M. F. Attallah, N. S. Awwad and H. F. Aly, Environmental Radioactivity of TE-NORM Waste Produced from Petroleum Industry in Egypt: Review on Characterization and Treatment, Natural Gas - Extraction to End Use, ed. S. Gupta, InTech, 2012, ISBN: 978-953-51-0820-7, DOI: 10.5772/39223, http://www.intechopen.com/books/natural-gas-extraction-toend-use/environmental-radioactivity-of-te-norm-wasteproduced-from-petroleum-industry-in-egypt-review-on-cha.

21 H. F. Gesell, Occupational Radiation Exposure Due To ${ }^{222} \mathrm{Rn}$ in Natural Gas And Natural Gas Products, Health Phys., 1975, 29, 681-687.

22 W. A. Kolb and M. Wojcik, Enhanced radioactivity due to natural oil and gas production and related radiological problems, Sci. Total Environ., 1985, 45(C), 77-84.

23 J.-E. B. Hajer Hrichi and S. Baccouche, Evaluation of radiological impacts of tenorm in the Tunisian petroleum industry, J. Environ. Radioact., 2013, 115, 107-113. 
24 M. S. Al-Masr, Spatial and monthly variations of radium isotopes in produced water during oil production monthly variations of radium isotopes in produced water during oil production, Appl. Radiat. Isot., 2006, 64(1), 615-623.

25 I. Othman and M. Al-Masri, Disposal Strategy for NORM Waste Generated by the Syrian Oil Industry, Conference: The International Symposium on the Disposal of Low Activity Waste, Cordoba, Spain, 2004.

26 I. Othman and M. Al-Masri, Naturally occurring radioactive materials (NORM) wastes in oil fields are a radiological problem, but they are useful tools, Conference: International congress of the International Radiation Protection Association (IRPA): Strengthening radiation protection worldwide, Buenos Aires (Argentina), 2008.

27 O. Haitham Adnan and N. Kadhim, Measurement the radioactivity of some local and imported oil products and for AL-Dora Refinery using gamma spectroscopy, MSc thesis, Al - Mustansiriyah University, 2016.

28 A. S. Habib, Measurement of NORM in non-uniform scale samples from Libyan oil Industry using gamma spectroscopy and Monte Carlo technique, $\mathrm{PhD}$ thesis, University of Surrey, 2012.

29 R. A. Zielinski and J. K. Otton, Naturally Occurring Radioactive Materials (NORM) in Produced Water and OilField Equipment-An Issue for the Energy Industry, USGS Fact Sheet 142-99, 1999.

30 M. S. Al-Masri and H. Suman, Norm waste management in the oil and gas industry: the Syrian experience, J. Radioanal. Nucl. Chem., 2003, 256(1), 159-162.

31 M. Al-Masri, et al., Radiation Protection and Waste Safety in the Oil and Gas Industry, Report number 34: Safety Report 34 Affiliation, International Atomic Energy Agency (IAEA), 2004.

32 N. M. I. S. Shawky, H. Amer, A. A. Nada and T. M. Abd ElMaksoud, Characteristics of NORM in the oil industry from Eastern and Western deserts of Egypt, Appl. Radiat. Isot., 2001, 55, 135-139.

33 H. B. Spitz, Effect of leachability on environmental risk assessment for naturally occurring radioactive materials (NORM) in petroleum oil field, Health Phys., 1996, 78(2), 191-198.

34 G. H. Otto, A National Survey on Naturally Occurring Radioactive Materials (NORM) in Petroleum Producing and Gas Processing Facilities, The American Petroleum Institute, Dallas, United States Texas, 1989.

35 N. S. Awwad, M. F. Attallah, E. M. El-Afifi, H. A. Ibrahium and H. F. Aly, Overview about Different Approaches of Chemical Treatment of NORM and TE-NORM Produced from Oil Exploitation, Advances in Petrochemicals, ed. V. Patel, InTech, 2015, ISBN: 978-953-51-2176-3, http:// www.intechopen.com/books/advances-in-petrochemicals/ overview-about-different-approaches-of-chemicaltreatment-of-norm-and-te-norm-produced-from-oil-expl.

36 M. H. Paranhos Gazineu, A. A. De Araújo, Y. B. Brandão, C. A. Hazin and J. M. D. O. Godoy, Radioactivity concentration in liquid and solid phases of scale and sludge generated in the petroleum industry, J. Environ. Radioact., 2005, 81(1), 47-54.
37 I. Doyi, D. Essumang and S. Dampare, Technologically Enhanced Naturally Occurring Radioactive Materials (TENORM) in the Oil and Gas Industry: a review, Rev. Environ. Contam. Toxicol., 2015, 238, 107-119.

38 J. Naerheim, Mercury Guideline for the Norwegian Oil and Gas Industry, Conference: SPE European HSE Conference and Exhibition, 2013.

39 IAEA, Radiation Protection and the Management of Radioactive Waste in the Oil and Gas Industry, International Atomic Energy Agency, Vienna, 2010, p. 40.

40 F. Steinhäusler, Radiological Impact on Man and the Environment from the Oil and Gas Industry: Risk Assessment for the Critical Group, 2005, vol. 41, pp. 129-134.

41 N. F. Khadhim and O. H. Adnan, Measurement of natural radioactivity in Al-Dora Refinery by using (HPGe) detector, Adv. Appl. Sci. Res., 2016, 7(4), 197-208.

$42 \mathrm{~J}$. M. Neff, Book reviews - Bioaccumulation in marine organisms-effect of contaminants from oil well produced water, J. Exp. Mar. Biol. Ecol., 2003, 287, 135-137.

43 E. M. El Afifi and N. S. Awwad, Characterization of the TENORM waste associated with oil and natural gas production in Abu Rudeis, Egypt, J. Environ. Radioact., 2005, 82(1), 7-19.

44 K. P. Smith, An overview of naturally occurring radioactive materials (NORM) in the petroleum industry, Report by: Argonne National Lab., Environmental Assessment and Information Sciences Div, United States, 1992.

45 F. Bou-Rabee, A. Z. Al-Zamel, R. A. Al-Fares and H. Bem, Technologically enhanced naturally occurring radioactive materials in the oil industry (TENORM). A review, Nukleonika, 2009, 54(1), 3-9.

46 H. M. Shams, D. A. Bradley and P. H. Regan, Determination of levels of naturally occurring radioactive materials in lagoon samples containing produced water from the Minagish oil field in the state of Kuwait, Radiat. Phys. Chem., 2017, 137, 193-197.

47 S. Fares, Measurements of natural radioactivity level in black sand and sediment samples of the Temsah Lake beach in Suez Canal region in Egypt, J. Radiat. Res. Appl. Sci., 2017, 1, 1-10.

48 N. W. S. C. S. Document, Detailed Overview of NORM Waste Management in Each of the UK NORM industry Sectors, 2014, https://www.gov.uk/oil-and-gas-uk-field-data\#oi-and-gas-wells.

$49 \mathrm{~W}$. Knaepen, et al., State-of-the-art of NORM nuclide determination in samples from oil and gas production: validation of potential standardization methods through an interlaboratory test programme, J. Radioanal. Nucl. Chem., 1995, 198(2), 323-341.

$50 \mathrm{H}$. Vandenhove, European sites contaminated by residues from the ore-extracting and-processing industries, in International Congress Series, 2002, vol. 1225, pp. 307-315.

51 A. S. Paschoa and J. Godoy, The areas of high natural radioactivity and TENORM wastes, Int. Congr. Ser., 2002, 1225, 3-8.

52 A. S. Paschoa, More than forty years of studies of natural radioactivity in Brazil, Cognizant Communication Corporation, Technology, vol. 7, no. 2-4, 2000, pp. 193-212(20). 
53 L. A. Bolling, J. O. Lubenau and D. A. Nussbaumer, Regulation of naturally occurring and acceleratorproduced radioactive materials: an update, Report by: Nuclear Regulatory Commission, Washington, D.C., USA, 2019.

54 F. J. Bradley, NCRP Report No. 139, risk-based classification of radioactive and hazardous chemical wastes, Health Phys., 2003, 85(6), 759-760.

55 D. A. Nussbaumer, et al., Regulation of naturally occurring and accelerator-produced radioactive materials. A Task Force review, Report to Nuclear Regulatory Commission, Washington, D.C., USA, 1977, vol. 8, p. 0301.

56 A. Edmondson and B. Moingeon, From organizational learning to the learning organization, Manag. Learn., 1998, 29(1), 5-20.

57 A. N. Mironov, A. V. Gebruk, L. I. Moskalev, et al., Bbiogeograaphical patterns of the hydrothermal vent fauna: a comparison with (non-vent biogeography), Cah. Biol. Mar., 1998, 39, 367-368.

58 F. Steinhäusler, Geohazards due to technologically enhanced natural radioactive wastes, Acta Geophys., 2010, 58(5), 922-938.

59 G. Marović and J. Senčar, Assessment of radioecological situation of a site contaminated by technologically enhanced natural radioactivity in Croatia, J. Radioanal. Nucl. Chem., 1999, 241(3), 569-574.

60 M. Križman, P. Stegnar and V. Miklavčič, Mercury ore processing-A new source of technologically enhanced natural radioactivity, Environ. Int., 1996, 22(1), 251-258.

61 D. Brajnik, M. Krizman, I. Kobal and P. Stegnar, Sources of Technologically Enhanced Natural Radioactivity and Their Impact in Slovenia (Yugoslavia), Radiat. Prot. Dosim., 1988, 24(1-4), 551-554.

62 IAEA, Extent of Environmental Contamination by Naturally Occurring Radioactive Material (NORM) and Technological Options for Mitigation, Report No. 419, International Atomic Energy Agency, Vienna, 2003.

63 R. O. Abdel Rahman, M. Elmesawy, I. Ashour and Y.-T. Hung, Remediation of NORM and TENORM contaminated sites-Review article, Environ. Prog. Sustainable Energy, 2014, 33(2), 588-596.

64 Perma-Fix Environmental Services, Technologically Enhanced Naturally Occurring Radioactive Materials (Tenorm) Study Report, Pennsylvania Department of Environmental Protection Rachel Carson State Office Building, 2016.

65 F. Aardwetenschappen, U. Utrecht and A. P. Schmidt, Naturally Occurring Radioactive Materials in the gas and oil industry, Department of Geochemistry, Utrecht University, The Netherlands, 2000, p. 195.

66 I. Al-Hamarneh, N. Alkhomashi and F. Almasoud, Study on the radioactivity and soil-to-plant transfer factor of ${ }^{228} \mathrm{Ra}$, ${ }^{234} \mathrm{U}$ and ${ }^{238} \mathrm{U}$ radionuclides in irrigated farms from the northwestern Saudi Arabia, J. Environ. Radioact., 2016, 160, 1-7.

67 A. Bell, M. A. Hernandez, K. Kremer and D. Mallinson, Geologic History, Hydrology, and Current Public Policy:
The Case of Radionuclides and Water Quality in Pennsylvania's Marcellus Shale Region, Case Studies in the Environment, 2018, 2, 1-11, DOI: 10.1525/ cse.2018.001388.

68 K. P. Smith, D. L. Blunt, G. P. Williams and C. L. Tebes, Radiological Dose Assessment Related to Management of Naturally Occurring Radioactive Materials Generated by the Petroleum Industry, SPE/EPA Exploration and Production Environmental Conference, Society of Petroleum Engineers, Houston, Texas, 1995, p. 10.

69 S. Moebius, R. Moebius, M. Bartenbach and T. Ramamonjisoa, Liquid scintillation for NORM in the oil and gas industry, in 12th International congress of the International Radiation Protection Association (IRPA): strengthening radiation protection worldwide, Buenos Aires, Argentina, 2008.

70 J. Thompson, I. Frank Costello, P. Z. Fahd, L. Gary Forsee, A. Steve Gavitt, N. Y. B. Goretzki, and N. D. Dale Patrick, E-42 Task Force Report Review of Tenorm In The Oil \& Gas Industry, Nuclear Regulatory Commission, U.S, 2015.

71 J. Kónya and N. Nagy, Radioactive Decay, in Nuclear and Radiochemistry, Elsevier, 2nd edn, 2018, pp. 49-84.

72 G. B. Saha, Radioactive Decay, in Fundamentals of Nuclear Pharmacy, Springer, 7th edn, 2018, pp. 11-32.

73 T. Hobbes, Chapter 13: radioactive decay, University of Michigan, 2019, pp. 64-69.

74 S. D'Auria, Radioactive Decays, in Introduction to Nuclear and Particle Physics, Springer, 2018, pp. 51-70.

75 H. Shams, D. Bradley, H. Alshammari and P. Regan, A "Review of the Evaluation of TENORM Levels at the Produced Water Lagoon of the Minagish Oil Field Using High-Resolution Gamma-ray Spectrometry", Radiat. Phys. Chem., 2017, 140, 122-126.

76 T. Sattler, PA-DEP Finds Little Potential Health Exposure Risks with Marcellus Natural Gas TENORM, 2015, https:// www.entecheng.com/en-us/blog/pa-dep-finds-littlepotential-health-exposure-risks-with-marcellus-natural-gastenorm-bpid_351.aspx.

77 M. F. Attallah, M. A. Hilal and Y. T. Mohamed, Preliminary investigations on reducing the high radiation risk level of TENORM scale waste from petroleum industry, Radiochim. Acta, 2018, 106(9), 793-800, DOI: 10.1515/ract2017-2904.

78 M. Al-Masri, et al., Radiation Protection and the Management of Radioactive Waste in the Oil and Gas Industry, IAEA Safety Report Series No. 34 Publisher, International Atomic Energy Agency, Vienna, 2003.

79 E. El Afifi, N. Awwad and M. Hilal, Sequential chemical treatment of radium species in TENORM waste sludge produced from oil and natural gas production, J. Hazard. Mater., 2009, 161(2-3), 907-912.

80 A. P. Production, Exploration Association (APPEA) Limited (2002), Guidel. Nat. Occur. Radioact. Mater. APPEA, Aust, APPEA confrence, 21-24 April, 2002.

81 A. N. Al-farsi, Radiological Aspects of Petroleum Exploration and Production in the Sultanate of Oman, PhD thesis, Queensland University of Technology, 2008. 
82 D. O. Kpeglo, Radiation Exposure to Natural Radioactivity in Crude Oil and Petroleum Waste from Oil Fields in Ghana; Modelling, Risk Assessment and Regulatory Controls, PhD thesis, University Of Ghana, 2015.

83 EPA, TENORM: Oil and Gas Production Wastes, 2017, https:// www.epa.gov/radiation/tenorm-oil-and-gas-productionwastes, accessed: 17-Feb-2019.

84 G. Raeburn, Low Specific Activity Scale: Origin, Treatment and Disposal, Report No. 6.6/127, E\&P Forum, 1988.

85 ICRP, Radiological Protection from Naturally Occurring Radioactive Material (NORM) in Industrial Processes, Draft Report For ConsultatioN, International Commission on Radiological Protection, Ann. ICRP, ref: 4811-39953019, 2018.

86 G. Jonkers, F. A. Hartog, W. A. I. Knaepen, P. F. J. Lancee, Characterization of NORM in the oil and gas production (E\&P) industry, Proc. Int. Symp. On Radiological Problems with Natural Radioactivity in the Non-Nuclear Industry, Amsterdam, The Netherlands, 1997, ch. 4.7, pp. 23-47.

87 S. K. Sahoo, et al., Natural radioactivity in roadside soil along Jamshedpur-Musabani road: a mineralised and mining region, Jharkhand and associated risk, Radiat. Prot. Dosim., 2010, 140(3), 281-286.

88 A. D. Bajoga, N. Alazemi, H. Shams, P. H. Regan and D. A. Bradley, Evaluation of naturally occurring radioactivity across the State of Kuwait using highresolution gamma-ray spectrometry, Radiat. Phys. Chem., 2017, 137, 203-209.

89 M. A. A. N. Abdulbary Kasem, Radioactive Contamination of Material Naturally and Decontamination Methods in the Oil and Gas Industry, Radiation Physics \& Protection Conference, 13-15 November 2006, Beni Sueif-Fayoum, Egypt, 2006.

90 E. Rowan, M. Engle, C. Kirby and T. Kraemer, Radium Content of Oil-and Gas-Field Produced Waters in the Northern Appalachian Basin (USA): Summary and Discussion of Data, Scientific Investigations Report 20115135, Geological Survey, Reston, Virginia U.S., 2011.

91 I. Doyi, O. C. Oppon, E. T. Glover, G. Gbeddy and W. Kokroko, Assessment of occupational radiation exposure in underground artisanal gold mines in Tongo, Upper East Region of Ghana, J. Environ. Radioact., 2013, 126, 77-82.

92 I. Badrul, Petroleum sludge, its treatment and disposal: a review, Int. J. Chem. Sci., 2015, 13(4), 1584-1602.

93 I. M. E.-S. A. Othman, I. H. Saleh, Z. F. Ghatass and M. A.-A. Metwally, Radiological Risk Assessment in a Type of Complex Petroleum Refinery in Egypt, Arab J.Nucl.Sci.Appl., 2018, 51(4), 31-43.

94 Y. Ö. Özkök, A. Parmaksız, Y. Ağuş, F. Bulgurlu, E. Bulur and T. Öncü, Measurement of enhanced radium isotopes in oil production wastes in Turkey, J. Environ. Radioact., 2015, 141, 82.

95 M. S. Hamlat, S. Djeffal and H. Kadi, Assessment of radiation exposures from naturally occurring radioactive materials in the oil and gas industry, Appl. Radiat. Isot., 2001, 55(1), 141-146.
96 S. E. Snavely, Radionuclides in produced water-a literature review, American Petroleum Institute Publication, no. 5404, 1989, pp. 1-85.

97 J. S. Ball, W. J. Wenger, H. J. Hyden, C. A. Horr and A. T. Myers, Metal Content of Twenty-Four Petroleums, J. Chem. Eng. Data, 1960, 5(4), 553-557.

98 W. F. Bakr, Assessment of the radiological impact of oil refining industry, J. Environ. Radioact., 2010, 101(3), 237243.

99 N. Hassan, N. A Mansou, S. Salama and M. S. Seoud, Assessment of Radiological Hazards of Using Petroleum Raw Materials and their Waste, Radiat. Prot. Dosim., 2019, 1-13.

100 H. A. H. K. K. Ali and S. S. Shafik, Radiological Assessment of NORM Resulting From Oil and Gas Production Processing in South Rumaila Oil Field, Southern Iraq, Iraqi J. Sci., 2017, 58(2), 1037-1050.

101 K. Ali, Radiological hazard Assessment Due to Natural Occurring Radioactive Materials (NORM) in Oil and Gas Production Industry East Baghdad Oil Field, Iraqi J. Sci., 2017, 58(1A), 115-126.

102 T. R. Ajayi, N. Torto, P. Tchokossa and A. Akinlua, Natural radioactivity and trace metals in crude oils: implication for health, Environ. Geochem. Health, 2009, 31(1), 61-69.

103 B. B. Babatunde, F. D. Sikoki, G. O. Avwiri and Y. E. ChadUmoreh, Review of the status of radioactivity profile in the oil and gas producing areas of the Niger delta region of Nigeria, J. Environ. Radioact., 2019, 202, 66-73.

104 E. O. Darko, D. O. Kpeglo, H. Akaho, C. Schandorf, P. Adu, A. Faanu, E. Abankwah, H. Lawluvi and R. Awudu, Radiation Doses and Hazards from Processing of Crude Oil at the Tema Oil Refinery in Ghana, Radiat. Prot. Dosim., 2012, 148(3), 318-328.

105 E. R. Landa, Naturally occurring radionuclides from industrial sources: characteristics and fate in the environment, Radioact. Environ., 2007, 10, 211-237.

106 R. A. E. Abdelmoniem, et al., Measurement of Activity Concentration, Absorbed Dose Rate and Annual Effective Dose of Natural Occurring Radioactive Material (NORM) in Samples Encountered During Oil \& Gas Industry, IOSR J. Appl. Phys., 2016, 8(5), 89-95.

107 M. S. Al-Masri and K. Haddad, NORM emissions from heavy oil and natural gas fired power plants in Syria, $J$. Environ. Radioact., 2012, 104, 71-74.

108 H. a. M. Puad and M. Y. M. Noor, Behaviors of ${ }^{323} \mathrm{Th},{ }^{238} \mathrm{U}$, ${ }^{228} \mathrm{Ra}$ and ${ }^{226} \mathrm{Ra}$ on combustion of crude oil terminal sludge, J. Environ. Radioact., 2004, 73(3), 289-305.

109 S. El-Kameesy, H. Diab, A. B. Ramadan and O. R. Megahid, Determination of Naturally Occurring Radioactive Material in the Egyptian Oil, Arab J. Nucl. Sci. Appl., 2017, 50(4).

110 A. Abbady, A. M. El-Arabi and W. Rashed, Assessment of radioactivity levels in some oil samples from the western desert, Egypt, Nucl. Sci. Tech., 2007, 18(2), 118-122.

111 H. Mohammed, S. Sadeek, A. Rehab Mahmoud, H. Diab and D. Zaky, Natural radioactivity and radiological hazard assessment of Egyptian oil ashes, Environ. Sci. Pollut. Res. Int., 2016, 23(15), 15584-15592. 
112 H. Barros, L. Sajo-Bohus, J. M. Abril and E. D. Greaves, Radioactivity concentration and heavy metal content in fuel oil and oil-ashes in Venezuela, Radioprotection, 2005, 4(1), 183-189.

113 K. P. Smith, Overview of Naturally Occurring Radioaiv Materials (NORM) in the Petroleum Industry, Argonne National Laboratory, Argonne, 1992.

114 R. Gardner, Overview and Characteristics of Some Occupational Exposures and Health Risks on Offshore Oil and Gas Installations, Ann. Occup. Hyg., 2003, 47(3), 201210.

115 J. A. Veil, Options and Cost for Disposal of NORM Waste, 5th Int. Pet. Environ. Conf., 1998, pp. 1-16.

116 J. A. Veil, Options and Cost for Disposal of NORM Waste, 5th Int. Pet. Environ. Conf., 1998, pp. 1-16.

117 M. S. Hamlat, H. Kadi, S. Djeffal and H. Brahimi, Radon concentrations in Algerian oil and gas industry, Appl. Radiat. Isot., 2003, 58(1), 125-130.

118 R. Fisher, Geologic, Geochemical, and Geographic Controls on NORM in Produced Water from Texas Oil, Gas, and Geothermal Reservoirs, Austin, Texas, U.S., 1996.

119 T. Gäfvert, I. Færevik, Natural Radioactivity in Produced Water from the Norwegian Oil and Gas Industry in 2003, Norwegian Radiation Protection Authority Postboks, Norway, 2005.

120 N. R. C., Evaluation of Guidelines for Exposures to Technologically Enhanced Naturally Occurring Radioactive Materials Commission on Life Council, National Research, National Academy Press, Washington, 1999.

121 M. D. Ali Hosseini, J. E. Brown and J. Gwynn, Environmental, Health, and Safety Guidelines for Offshore Oil and Gas Development, Sci. Total Environ., 2012, 438, 325-333.

122 M. D. Ali Hosseini, J. E. Brown and J. P. Gwynn, Review of research on impacts to biota of discharges of naturally occurring radionuclides in produced water to the marine environment, Sci. Total Environ., 2012, 438, 325-333.

123 C. Hanfland, Radium-226 and Radium-228 in the Atlantic Sector of the Southern Ocean, $\mathrm{PhD}$ thesis, Universität Bremen, 2002.

124 A. Fakhru'l-Razi, A. Pendashteh, L. C. Abdullah, D. R. A. Biak, S. S. Madaeni and Z. Z. Abidin, Review of technologies for oil and gas produced water treatment, $J$. Hazard. Mater., 2009, 170(2-3), 530-551.

125 J. O. Robertson and G. V. Chilingar, Environmental Aspects of Oil and Gas Production, Scrivener Publishing - Wiley, Beverly, USA, 2017.

126 R. L. Ericksen, Evaluations of Radionuclides of Uranium, Thorium, and Radium Associated Vdith Produced Fluids, Precipitates, and Sludges from Oil, Gas, and Oilfield Brine Injection Wells in Mississippi, No. DOE/BC/15035-1, National Petroleum Technology Office, Tulsa, OK, US, 1999.

127 C. Swann, J. Matthews, R. Ericksen and J. Kuszmaul, Evaluations of Radionuclides of Uranium, Thorium, and Radium Associated with Produced Fluids, Precipitates, and Sludges from Oil, Gas, and Oilfield Brine Injection Wells in Mississippi, University of Mississippi, U.S., 2004.
128 N. M. S. F. Jerez Vegueria and J. M. Godoy, Environmental impact studies of barium and radium discharges by produced waters from the Bacia de Campos oil field offshore platforms Brazil, J. Environ. Radioact., 2002, 62, 29-38.

129 R. F. F. C. Testa, D. Desideri, M. A. Meli, C. Roselli, A. Bassignani and G. Colombo, Radiation Protection and Radioactive Scales in Oil and Gas Production, Health Phys., 1994, 67(1), 834-867.

130 D. Eriksen, et al., Radionuclides in produced water from Norwegian oil and gas installations - Concentrations and bioavailability, Czech. J. Phys., 2006, 56(4), 43-48.

131 R. D. Mohammad Ghafar and F. Marroshiah, Evaluation of Radioactivity and Potential Radiation Hazard of NORM waste due to Produced Water Draining in Crude Oil Tanks Area in Banyas, Tishreen Univ. J. Res. Sci. Stud., 2017, 39(3), 195-210.

132 M. S. A. Al-Masri, Determination of radioactive scales in oil industry using naturally occurring radioactive materials, Atomic Energy Commission of Syria, No. AECS-PR/FRSR357, 2006.

133 K. M. Zakaria, Radiological Impacts of Norm and Poly Aromatic Hydrocarbon in Petroleum Industry Process on Marine Ecosystem at the Red Sea, Egypt, Environ. Anal. Ecol. Stud., 2018, 1(4).

134 M. F. Attallah, E. M. El Afifi, N. S. Awwad and H. F. Aly, Comparative study on the radioactivity of TE-NORM in different components of oil separator tanks, Radiochim. Acta, 2013, 101, 57-65.

135 F. Moatar, S. R. Shadizadeh, A. R. Karbassi, E. Ardalani, R. Akbari Derakhshi and M. Asadi, Determination of naturally occurring radioactive materials (NORM) in formation water during oil exploration, J. Radioanal. Nucl. Chem., 2010, 283(1), 3-7.

136 C. N. D. P. Jodłowski, J. Macuda and J. Nowak, Radioactivity in wastes generated from shale gas exploration and production North Eastern Poland, J. Environ. Radioact., 2017, 175-176, 34-38.

137 E. Botezatu and C. Grecea, Radiological Impact Assessment on Behalf of Oil/Gas Industry, J. Prev. Med., 2004, 12(1-2), 16-21.

138 A. E. Pillay, F. M. Salih and M. I. Maleek, Radioactivity in oily sludge and produced waste water from oil: environmental concerns and potential remedial measures, Sustainability, 2010, 2(4), 890-901.

139 A. Faanu, Assessment of Public Exposure to Naturally Occurring Radioactive Materials from Mining and Mineral Processing Activities of Tarkwa Goldmine in Ghana, University of Science and Technology, Kumasi, 2011.

140 R. G.-T. a. D. O. Kpeglo, J. Mantero, E. O. Darko, G. EmiReynolds, A. Faanu, G. Manjon, I. Vioque and E. H. K. Akaho c, Radiochemical characterization of produced water from two production offshore oilfields in Ghana, J. Environ. Radioact., 2016, 152, 35-45.

141 C. P. O. E. O. Agbalagba and G. O. Avwiri, Activity concentration and radiological impact assessment of ${ }^{226} \mathrm{Ra},{ }^{228} \mathrm{Ra}$ and ${ }^{40} \mathrm{~K}$ in drinking waters from (OML) 30, 
58 and 61 oil fields and host communities in Niger Delta region of Nigeria, J. Environ. Radioact., 2013, 116, 197-200.

142 A. E. O. Avwiri Gregory and O. Esi Emmanuel1, Gamma spectroscopy analysis of produced water from selected flow stations in delta state, Nigeria, Int. J. Environ. Monit. Anal., 2013, 1(5), 167-174.

143 A. C. Canaoba, G. A. Gnoni and W. A. Truppa, NormPRODUCEDs in the oil and gas industry in Argentina, in 5th International Symposium on Naturally Occurring Radioactive Material, Sevilla, España, 19-22 marzo, 2007, pp. 34-42.

144 Continental SheIf Associates, Radionuclides, Metals, And Hydrocarbons in Oil and Gas Operational Discharges and Environmental Samples Associated with Offshore Production Facilities On the Texas/Louisiana Continental Shelf with an Environmental Assessment of Metals and Hydrocarbons, National Petroleum Technology Office U.S. Department Of Energy Tulsa, Oklahoma USA, 1999.

145 B. Mcdevitt, et al., Emerging investigator series: radium accumulation in carbonate river sediments at oil and gas produced water discharges: implications for beneficial use as disposal management, Environ. Sci.: Processes Impacts, 2018, 21(2), 324-338.

146 T. F. Kraemer and D. F. Reid, The Occurrence and Behavior of Radium in Saline Formation Water of the U.S. Gulf Coast Region, Isot. Geosci., 1984, (2), 153-174.

147 J. R. Frazier, Characterization of Naturally Occurring Radioactive Materials And Radiological Conditions In The Oil And Gas Field, Pennsylvania 15241, 2015.

148 D. H. S. R. H. B., A Study of NORM Associated with Oil and Gas Production Operations in California, Department of Health Services, Radiologic Health Branch and Department of Conservation, Division of Oil, Gas, and Geothermal Resources, 1996.

149 T. Zhang, Origin and Fate of Radium in Flowback and Produced Water from Marcellus Shale Gas Exploration, Bachelor, University of Pittsburgh, 2015.

150 H. L. H. B. B. Bandong, S. A. Kreek, J. M. Bazan, P. C. Torretto, J. A. Dixon, W. L. Edwards, E. B. Guthrie, M. A. Ruth and F. A. Zaka, Validation of a Gamma Spectrometric Method for the Measurement of ${ }^{226,228} \mathrm{Ra}$ in Environmental Media Relevant to the Offshore Oil and Gas Industry, J. Radioanal. Nucl. Chem., 2005, 264(2), 429435.

151 C. Christie, Disposal of Produced Water from Oil \& Gas Exploration: Environmental Impacts on Waterways in Western Pennsylvania, Duke University, 2012.

152 H. K. Khalilova, Research into the Radionuclide Pollution of Ecosystem on the Territory of Oil Fields of Absheron Peninsula, Sustainability, 2016, 3, 233-237.

153 L. D. Plyatsuk, O. A. Burla, I. Y. Ablieieva, L. L. Hurets and I. O. Roy, Investigation of produced waters radioactivity of oil and gas deposits in the Dnieper-Donets province, $J$. Eng. Sci., 2017, 4(2), G17-G21.

154 J. H. Anna Mykowska, Original Research Natural Radioactivity of Solid and Liquid Phases from Shale oil and Gas Prospecting in Pomerania, Pol. J. Environ. Stud., 2014, 23(6), 2137-2142.

155 M. F. Abdel-sabour, E. Atomic and E. Authority, NORM in Waste Derived from Oil and Gas Production, Conference: Middle East Waste Management Summit, Sofitel Cairo ElGezirah Hotel-Egypt, 2015.

156 O. J. G. Vetter and R. C. Phillips, Prediction of Deposition of Calcium Sulfate Scale Under Down-Hole Conditions, J. Pet. Technol., 1970, 22(10), 1299-1308.

157 O. J. Vetter, V. Kandarpa and A. Harouaka, Prediction of Scale Problems Due to Injection of Incompatible Waters, J. Pet. Technol., 1982, 34(No. 2), 273-284.

158 M. H. P. Gazineu, et al., Radium-226 and Radium-228 in scale and sludge generated in the petroleum industry, Proceedings of the 11th International Congress of the International Radiation Protection Association, 2004.

159 R. P. d. C. José Marcus Godoy, ${ }^{226} \mathrm{Ra}$ and ${ }^{228} \mathrm{Ra}$ in scale and sludge samples and their correlation with the chemical composition, J. Environ. Radioact., 2003, 70, 199-206.

160 G. Xhixha, et al., The worldwide NORM production and a fully automated gamma-rayspectrometer for their characterization, J. Radioanal. Nucl. Chem., 2013, 295(1), 445-457.

161 M. H. Gazineu and C. Hazin, Radium and potassium-40 in solid wastes from the oil industry, Appl. Radiat. Isot., 2008, 66(1), 90-94.

$162 \mathrm{M}$. H. Gazineu, Chemical and mineralogical characterization of waste generated in the petroleum industry and its correlation with ${ }^{226} \mathrm{Ra}$ and ${ }^{228} \mathrm{Ra}$ contents, Radioprotection, 2005, 40(s1), S753-S758.

163 M. S. Al-Masri and A. Aba, Distribution of scales containing NORM in different oilfields equipment, Appl. Radiat. Isot., 2005, 63(4), 457-463.

164 L. Al Attar, W. Doubal, J. Al Abdullah, H. Khalily, B. Abdul Ghany and B. Safia, Characterization of NORM solid waste produced from the petroleum industry, Environ. Technol., 2014, 36(9), 1104-1113.

165 L. Al Attar, B. Safia and B. A. Ghani, Radiological and chemical characterisation of scales generated by oil industry and treatment for long-term storage, Atomic Energy Commission of Syria, No. AECS-PR/FRSR 656, 2016, https://inis.iaea.org/search/search.aspx? origq $=\mathrm{RN}: 49055432$.

166 J. Al Abdullah, M. Al-Masri, Y. Amin, H. Khalily, M. Ammar and S. Nassour, An innovative procedure for NORM scales treatment and radionuclides separation, Appl. Radiat. Isot., 2017, 125, 139-143.

167 L. Al Attar, B. Safia, B. A. Ghani and J. Al Abdulah, Recovery of NORM from scales generated by oil extraction, J. Environ. Radioact., 2016, 153, 149-155.

$168 \mathrm{~J}$. Garner, Industrial radioactivity in the UK's onshore oil and gas Industrial radioactivity in industry, Loughborough Universit, 2017.

169 J. Garner, J. Cairns and D. Read, NORM in the East Midlands' oil and gas producing region of the UK, Appl. Radiat. Isot., 2015, 150, 139-143.

170 S. El-Kameesy, H. Diab, A. B. Ramadan and O. R. Megahid, Assessment of Radioactive Concentrations in the Egyptian 
Natural Gas Grid and Their Relevant Impacts, Am. J. Phys. Appl., 2016, 4(6), 152-157.

171 M. Abo-Elmagd, H. A. Soliman, K. A. Salman and N. M. ElMasry, Radiological hazards of TENORM in the wasted petroleum pipes, J. Environ. Radioact., 2010, 101(1), 51-54.

172 M. Hilal, H. M. Abdelbary and G. G. Mohamed, Physicochemical and Radiation Hazardous Properties of Scale TENORM Waste: Evaluation by Different Analytical Techniques, Radiochemistry, 2018, 60(4), 444-449.

173 R. H. M. Omar, H. M. Ali, M. P. Abu, K. M. Kontol, Z. Ahmad, S. H. S. S. Ahmad and I. Sulaiman, Distribution of radium in oil and gas industry wastes from Malaysia, Appl. Radiat. Isot., 2004, 60, 779-782.

174 P. Varskog and H. Aamlid, Assessment, Treatment and Management of NORM in the Norwegian Oil and Gas Industry, in Proceedings of the 9th EAN ALARA Workshop, 2005, vol. 18, p. 21.

175 S. Landsberger, G. George, R. Lara, D. Tamalis, J. Louis Jean and K. Dayman, Analysis of Naturally Occurring Radioactive Material Using Neutron Activation Analysis and Passive Compton Suppression Gamma-Ray Spectrometry, Nukleonika, 2012, 57(4), 461-465.

176 G. G. S. Landsberger and S. G. Landsberger, Radioactive Waste in Oil Exploration, IAEA, Texas, USA, 2014.

177 G. J. White and A. S. Rood, Radon emanation from NORMcontaminated pipe scale and soil at petroleum industry sites, J. Environ. Radioact., 2001, 54(3), 401-413.

178 S. Landsberger, et al., Determination of ${ }^{226} \mathrm{Ra},{ }^{228} \mathrm{Ra}$ and ${ }^{210} \mathrm{~Pb}$ in NORM products from oil and gas exploration: problems in activity underestimation due to the presence of metals and self-absorption of photons, J. Environ. Radioact., 2013, 125, 23-26.

179 J. K. W. Donald and J. Fournier Jr, The Debate Over Land Farming Naturally Occurring Radioactive Material (NORM) Generated by the Oil and Gas Industry in Mississippi, in 2000 Annual Conference, 2000, pp. 5.614.15.614.4.

180 D. K. R. García-Tenorio, J. Mantero, G. Manjón and I. Vioque, Radioactivity Levels in Scales Generated from Crude Oil Production in Ghana, Ghana Atomic Energy Commission, 2015.

181 S. N. L. K. K. Kadyrzhanov, et al., Radioactive components of scales at the inner surface of pipes in oilfields of Kazakhstan, J. Radioanal. Nucl. Chem., 2005, 264(2), 413-416.

182 P. Galitskaya, L. Biktasheva, A. Saveliev, S. Ratering, S. Schnell and S. Selivanovskaya, Response of soil microorganisms to radioactive oil waste: results from a leaching experiment, Biogeosciences, 2015, 12(12), 3681-3693.

183 D. S. Wisnubroto, Implementasi Bss Pada Pengelolaan NormTenorm, Puslitbang Teknologi Maju - BATAN Jogjakarta, 12 Juli, 2005, pp. 45-52, ISS. 0216-3128.

184 G. M. Heath, R. A. Heath and Z. Dundr, Paraffinic sludge reduction in crude oil storage tanks through the use of shearing and resuspension, Pet. Sci., 2004, 9, 184-188.

185 J. Bakri and R. Siregar, Radiation and Radioactivity Levels Survey of Naturally Occurring Radioactive Materials (NORM) at PT Caltex Pacific Indonesia, Proceedings of the
Seminar on Environmental and Radiation Safety Aspect at Non-nuclear Industry, 2003, vol. 42, p. 48.

186 M. Attallah, M. Hamed, E. El Afifi and H. Aly, Removal of ${ }^{226} \mathrm{Ra}$ and ${ }^{228} \mathrm{Ra}$ from TENORM sludge waste using surfactants solutions, J. Environ. Radioact., 2015, 139, 78-84.

187 M. Hilal, M. Attallah, G. Mohamed and M. Fayez-Hassan, Evaluation of radiation hazard potential of TENORM waste from oil and natural gas production, J. Environ. Radioact., 2014, 136, 121-126.

188 T. Strand, NORM in the Norwegian Oil and Gas Industry Activity Levels, Occupational Doses and Protective Measures, in The 11th IRPA International Congress..., ipen.br, vol. 55, 2004, pp. 1-5.

189 G. Xhixha, et al., Chemosphere A century of oil and gas exploration in Albania: assessment of Naturally Occurring Radioactive Materials (NORMs), Chemosphere, 2015, 139, 30-39.

190 L. E. Matta, J. Godoy and M. Reis, Ra-226, Ra-228 and Th228 in scale and sludge samples from the Campos Basin oilfield E\&P activities, Radiat. Prot. Dosim., 2002, 102(2), 175-180.

191 A. Al-Futaisi, A. Jamrah, B. Yaghi and R. Taha, Assessment of alternative management techniques of tank bottom petroleum sludge in Oman, J. Hazard. Mater., 2007, 141(3), 557-564.

192 A. T. Al-Kinani, M. Hushari, I. A. Alsadig and H. Al-Sulaiti, NORM in soil and sludge samples in Dukhan oil Field, Qatar state, Donnish Journal of Research in Environmental Studies, 2015, 2(4), 37-43.

193 S.-Y. C. Siavash Sedighian, M. A. Abdoli, M. H. Niksokhan and M. J. Kim, Radiological dose assessment of naturally occurring radioactive materials generated by the petroleum industry in wildlife: a case study of chinkaras of Lavan Island, Iran, J. Adv. Environ. Health Res., 2014, 2(4), 215-222.

194 A. Taheri, A. Taheri, A. A. Fathivand and N. Mansouri, Risk assessment of naturally occurring radioactive materials (NORM) in the hydrocarbon sludge extracted from the south pars gas field in Iran, Process Saf. Environ. Prot., 2019, 125, 102-120.

195 J. Beretka and P. J. Mathew, Natural Radioactivity of Australian Building Materials, Industrial Wastes and ByProducts, Health Physics, 1985, 48(1), 87-95.

196 F. Alshahri and A. El-Taher, "Investigation of Natural Radioactivity Levels and Evaluation of Radiation Hazards in Residential-Area Soil Near a Ras Tanura Refinery, Saudi Arbia, Pol. J. Environ. Stud., 2018, 28(1), 25-34.

197 A. Ali, A. K. Mheemeed and H. I. Hassan, Concentration measurements of uranium, thorium and their daughter products in water produced from and near oil fields in north of Iraq using SSNTRD's passive method, $J$. Radioanal. Nucl. Chem., 2014, 303(1), 959-965.

198 A. Khodashenas, E. Roayaei, S. Mojtaba Abtahi and E. Ardalani, Evaluation of Naturally Occurring Radioactive Materials (NORM) in the South Western Oil Wells of Iran, J. Environ. Radioact., 2012, 71-75. 
199 N. Warner, C. A. Christie, R. B. Jackson and A. Vengosh, Impacts of Shale Gas Wastewater Disposal on Water Quality in Western Pennsylvania, Environ. Sci. Technol., 2013, 47(20), 11849-11857.

200 T. Pascal, Assessment of Radionuclide Concentrations and Absorbed Dose from Consumption of Community Water Supplies in Oil and Gas Producing Areas in Delta State, Nigeria, World J. Nucl. Sci. Technol., 2011, 1(3).

$201 \mathrm{~W}$. Abdellah and M. Al-Masri, Treatment of NORM contaminated soil from the oilfields, J. Environ. Radioact., 2013, 129, 63-67.

202 A. H. Taqi, L. Abdul, A. Al-Ani and A. M. Ali, Assessment of the natural radioactivity levels in Kirkuk oil field, J. Radiat. Res. Appl. Sci., 2016, 9, 337-344.

203 H. Alkinani, et al., Drilling Strategies to Control Lost Circulation in Basra Oil Fields, Iraq, The 2018 AADE Fluids Technical Conference and Exhibition held at the Hilton Houston, North Hotel, Houston, Texas, April 10-11, 2018.

204 P. Galitskaya, R. Gumerova, S. Ratering, S. Schnell, E. Blagodatskaya and S. Selivanovskaya, Oily waste containing natural radionuclides: does it cause stimulation or inhibition of soil bacterial community, $J$. Plant Nutr. Soil Sci., 2015, 178(6).

205 I. Doyi, D. Essumang, S. Dampare, D. Duah and F. Abeasi, Evaluation of radionuclides and decay simulation in a terrestrial environment for health risk assessment, Sci. Rep., 2017, 7(1), 16537.

206 E. O. Agbalagba, G. O. Avwiri and Y. E. Chad-Umoreh, $\gamma$ Spectroscopy measurement of natural radioactivity and assessment of radiation hazard indices in soil samples from oil fields environment of Delta State, Nigeria, J. Environ. Radioact., 2012, 109, 64-70.

207 I. Omoniyi, N. Jibiri, S. I. Bamidele and L. Najam, Evaluation of radiological hazards due to natural radioactivity in bituminous soils from tar-sand belt of southwest Nigeria using HpGe-Detector, International Journal of Radiation Research, 2018, 16(3), 351-362.

208 R. Saint-Fort, M. Alboiu and J. Hettiaratchi, Evaluation of TENORMs field measurement with actual activity concentration in contaminated soil matrices, Journal of Environmental Science and Health, 2007, 42(11), 1649-1654.

209 N. E. Lauer and A. Vengosh, Age Dating Oil and Gas Wastewater Spills Using Radium Isotopes and Their Decay Products in Impacted Soil and Sediment, Environ. Sci. Technol. Lett., 2016, 3(5), 205-209.

210 F. Abdullah, H. Saad and A. Farhan, An investigation of Naturally Occurring Radioactive Material (NORM) in Oilfields and Oil Lakes in Kuwait, Soc. Petrol. Eng. J., 2008, 1.

211 A. Bajoga, N. Alazemi, P. Regan and D. Bradley, Radioactive Investigation of NORM samples from southern Kuwait soil using high-resolution gamma-ray spectroscopy, Radiat. Phys. Chem., 2015, 116, 305-311.

212 J. Al Abdullah, M. Al-Masri, Y. Amin, I. Awad and Z. Sheaib, Chemical fractionation of radium-226 in NORM contaminated soil from oilfields, J. Environ. Radioact., 2016, 165, 47-53.
213 S. Sabbagh and S. Alhussen, Radioactive Pollutants in the Al-Amr Plants Soil from Petroleum Industry, Journal of Halab University Research, 2012, 1(85), 1-16.

214 T. Huang, Y. Hao, Z. Pang, Z. Li and S. Yang, Radioactivity of Soil, Rock and Water in a Shale Gas Exploitation Area, SW China, Water, 2017, 9(5), 299.

215 S. S. N. Gamage, R. M. T. S. Ratnayake, A. M. A. D. M. Senadhira, D. A. Weerasinghe and V. A. Waduge, Radioactive and Non-Radioactive Element Analysis of Dorado Gas Discovery of Sri Lanka and Their Influence on Natural Environment, J. Trop. For. Environ., 2018, 8(1), 55-63.

216 S. Ratnayake, S. Gamage, A. M. A. D. M. Senadhira, D. Weerasinghe and V. Waduge, NORM analysis of the reservoir sand section in the Dorado natural gas discovery, Mannar basin offshore Sri Lanka, J. Geol. Soc. India, 2017, 89(6), 683-688.

217 C. O. and G. C. Commission, Analysis of Naturally Occuring [sic] Radioactive Materials in Drill Cuttings, Greater Wattenberg Field Weld County, Colorado Oil and Gas Conservation Commission, Colorado, 2014.

218 A. Mykowska, A. Rogala, A. Kallas, J. Karczewski and H. Jan, Radioactivity of drilling cuttings from shale resources of the lower paleozoic Baltic basin, Physicochemical Problems of Mineral Processing, 2015, 51(2), 521-533.

219 O. Oni, et al., Natural Activity Concentrations and Assessment of Radiological Dose Equivalents in Medicinal Plants around Oil and Gas Facilities in Ughelli and Environs, Nigeria, Environ. Nat. Resour. Res., 2011, 1(1), DOI: 10.5539/enrr.v1n1p201.

220 A. A. Garibov, F. I. Mamedov, A. H. Isaev and J. A. Naghiyev, Radioecological Problems of Radioactively Contaminated Territories of The Absheron Peninssula, Chemical Problems, 2019, 17(1), 112-119.

221 R. S. Fisher, Naturally Occurring Radioactive Materials (NORM) in Produced Water and Scale from Texas On., Gas, and Geothermal Wells, The University of Texas at Austin, Bureau of Economic Geology, Geological Circular 9503D, Texas, 1995, p. 43.

$222 \mathrm{H}$. Hall, et al., Validation of a gamma-spectrometric method for the measurement of Ra-262, Ra-228 in environmental media relevant to the offshore oil and gas industry, J. Radioanal. Nucl. Chem., 2005, 264(2), 429-435.

223 A. Nelson, A. Knight, D. May, E. Eitrheim and M. Schultz, Naturally-Occurring Radioactive Materials (NORM) Associated with Unconventional Drilling for Shale Gas, Hydraulic fracturing: environmental issues, American Chemical Society, 2015, pp. 89-128.

224 A. El-Taher, Assessment of Natural Radioactivity Levels and Radiation Hazards for Building Materials Used in Qassim Area, Saudi Arabia, Rom. J. Phys., 2012, 57(3-4), 726-735.

225 C. P. Anekwe, U. L. Avwiri and G. O. Ononugbo, Measurement of Specific Activity Concentration of Radionuclides of ${ }^{226} \mathrm{Ra},{ }^{232} \mathrm{Th}$ and ${ }^{40} \mathrm{~K}$ in Selected Crude Oil Impacted Fields in The Niger Delta, IOSR J. Environ. Sci., Toxicol. Food Technol., 2016, 10(6), 2319-2399. 
226 B. Senthilkumar, V. Dhavamani, S. Ramkumar and P. Philominathan, Measurement of gamma radiation levels in soil samples from Thanjavur using $\gamma$-ray spectrometry and estimation of population exposure, $J$. Med. Phys., 2010, 35(1), 48-53.

227 A. P. P. \& E. Associatio, Guidelines For Naturally Occurring Radioactive Materials, (APPEA), APPEA, Australia, 2002, http://www.appea.com.au.

228 ICRP, 1990 Recommendations of the International Commission on Radiological Protection, ICRP Publication No. 60, International Commission on Radiological Protection, Pergamon Press, 1991.

229 J. Kvasnicka, Radiation Protection in the Offshore Petroleum Industry, In the proceedings of the 1996 International Congress on Radiation Protection of the International Radiation Protection Association, no. vol. 4, pp. 621-623, 1996.

230 E. Testai et al., Scientific Committee on Health, Environmental and Emerging Risks SCHEER FINAL OPINION on tolerable intake of aluminium with regards to adapting the migration limits for aluminium in toys, Technical Report, The SCHEER adopted this Opinion on 28 September, 2017.

231 G. E. Pataki and J. P. Cahill, An investigation of naturally occurring radioactive materials (NORM) in oil and gas wells in New York State, N. Y. State Dep. Environ. Conserv., 1999, 10-14.

232 I. Gorski and B. S. Schwartz, Environmental Health Concerns from Unconventional Natural Gas Development, in Oxford Research Encyclopedia of Global Public Health, 2019.

233 E. E. Oghenevovwero and O. A. Gregory, Radiological Hazards Assessment of Produced Water from Some Oil and Gas Flow Stations in Delta State, Nigeria, Journal of Scientific Research and Reports, 2018, 1-10.

234 E. Mohammed, A study of the natural radioactivity of the petroleum waste., Master thesis, AL-Nahrain University College, 2010.

235 E. W. Swiedler, L. A. Muehlenbachs, Z. Chu, J.-S. Shih and A. Krupnick, Should solid waste from shale gas development be regulated as hazardous waste, Energy Policy, 2019, 129, 1020-1033.

236 B. McDevitt, et al., Emerging investigator series: radium accumulation in carbonate river sediments at oil and gas produced water discharges: implications for beneficial use as disposal management, Environ. Sci.: Processes Impacts, 2019, 21(2), 324-338.

237 S. O. Oluyide, P. Tchokossa, M. M. Orosun, F. C. Akinyose, H. Louis and S. O. Ige, Natural Radioactivity and Radiological Impact Assessment of Soil, Food and Water around Iron and Steel Smelting Area in Fashina Village, Ile-Ife, Osun State, Nigeria, J. Appl. Sci. Environ. Manage., 2019, 23(1), 135-143.

238 L. Vergeynst, et al., In situ biodegradation, photooxidation and dissolution of petroleum compounds in Arctic seawater and sea ice, Water Res., 2019, 148, 459-468.
239 M. U. Khandaker, Y. M. Amin and D. A. Bradley, Elevated concentration of radioactive potassium in edible algae cultivated in Malaysian seas and estimation of ingestion dose to humans, Algal Res., 2019, 38, 101386.

240 C.-Y. Lin and Y.-M. Tseng, Effects of LED irradiation and sea water culture on the lipid characteristics of Nannochloropsis oculata, J. Renewable Sustainable Energy, 2018, 10(2), 23102.

241 T. L. Tasker, et al., Accuracy of methods for reporting inorganic element concentrations and radioactivity in oil and gas wastewaters from the Appalachian Basin, US based on an inter-laboratory comparison, Environ. Sci.: Processes Impacts, 2019, 21(2), 224-241.

242 L. E. Sweet, A. T. Revill, J. Strzelecki, S. E. Hook, J. M. Morris and A. P. Roberts, "Photo-induced toxicity following exposure to crude oil and ultraviolet radiation in 2 Australian fishes, Environ. Toxicol. Chem., 2018, 37(5), 1359-1366.

243 Z. M. S. Shlomy, M. M. A. L. S. Abo-adbba and M. A. Salem, Separation OfCrude Oil and Its Derivatives Spilled in seawater By Using Spinal Oxide (Environmental Aspects), University of Sabha, 2018.

244 B. U. Nwaka, G. O. Avwiri and C. P. Ononugbo, Radiological Risks Associated with Gross Alpha and Beta Activity Concentrations of Water Resources within Salt Water Lakes, Ebonyi State, Nigeria, International Journal of Tropical Disease and Health, 2018, 1-10.

245 A. E. Ite, T. A. Harry, C. O. Obadimu, E. R. Asuaiko and I. J. Inim, Petroleum hydrocarbons contamination of surface water and groundwater in the Niger Delta region of Nigeria, J. Environ. Pollut. Hum. Health, 2018, 6(2), 51-61.

246 A. Abbasi and F. Mirekhtiary, Lifetime risk assessment of Radium-226 in drinking water samples, International Journal of Radiation Research, 2019, 17(1), 163-169.

247 H. Pei, A. Abbaspourrad, W. Zhang, Z. Wu and D. A. Weitz, Water-Triggered Rapid Release of Biocide with Enhanced Antimicrobial Activity in Biodiesel, Macromol. Mater. Eng., 2019, 1900156.

248 K. L. Knee and A. E. Masker, Association between unconventional oil and gas (UOG) development and water quality in small streams overlying the Marcellus Shale, Freshw. Sci., 2019, 38(1), 113-130.

249 E. Gordon, The Oil \& Gas Industry: Failing to Properly Regulate Hydraulic Fracturing \& Placing Profits over Safety, Journal of Business, Entrepreneurship and the Law, 2018, 11, 131.

250 L. M. McKenzie, R. Z. Witter, L. S. Newman and J. L. Adgate, Human health risk assessment of air emissions from development of unconventional natural gas resources, Sci. Total Environ., 2012, 424, 79-87.

251 R. M. Purvis, et al., Effects of 'pre-fracking' operations on ambient air quality at a shale gas exploration site in rural North Yorkshire, England, Sci. Total Environ., 2019, 673, 445-454.

252 L. Y. W. Chua, et al., Characterisation of the Convective HotAir Drying and Vacuum Microwave Drying of Cassia alata: 
Antioxidant Activity, Essential Oil Volatile Composition and Quality Studies, Molecules, 2019, 24(8), 1625.

253 K. J. Black, S. McCoy and J. G. Weber, Fracking and indoor radon: spurious correlation or cause for concern?, $J$. Environ. Econ. Manag., 2019, 96, 255-273.

254 Y. Ajiboye, M. O. Isinkaye and M. U. Khanderkar, Spatial distribution mapping and radiological hazard assessment of groundwater and soil gas radon in Ekiti State, Southwest Nigeria, Environ. Earth Sci., 2018, 77(14), 545.

255 O. Belyaeva, K. Pyuskyulyan, N. Movsisyan, A. Saghatelyan and F. P. Carvalho, Natural radioactivity in urban soils of mining centers in Armenia: dose rate and risk assessment, Chemosphere, 2019, 225, 859-870.

256 F. M. Adebiyi and O. Ore, Measurement of radioactivity level of oil-contaminated soils around mechanic workshops for environmental impact assessment, Energy Sources, Part A, 2019, 1-10; O. Edomi, C. E. Mokobia and E. E. Oghenevovwero, Radiological Evaluation of Soil in Some Selected Oil and Gas Producing Communities in Delta Central, Delta State Nigeria, Asian J. Phys. Chem. Sci., 2018, 1-10.

257 I. N. Y. Doyi, D. K. Essumang, A. K. Agyapong and S. Asumadu-Sarkodie, "Soil-to-cassava transfer of naturally occurring radionuclides from communities along Ghana's oil and gas rich Tano Basin, J. Environ. Radioact., 2018, 182, 138-141.

258 M. K. Kazem, H. D. Al Ataby and S. S. Shafik, Natural radioactivity and radiation risk assessment in fly ash Soil and Water Samples Collected from and around of the ALZubaydiyah Thermal Power Plant, wasit, Iraq, J. Wassit Sci. Med., 2018, 11(1), 46-57.

259 G. O. Avwiri, C. P. Ononugbo and I. E. Nwokeoji, Radiation Hazard Indices and Excess Lifetime cancer risk in soil, sediment and water around mini-okoro/oginigba creek, Port Harcourt, Rivers State, Nigeria, Comprehensive Journal of Environment and Earth Sciences, 2014, 3(1), 38-50.

260 M. I. A. Adziz and K. S. Khoo, An assessment of absorbed dose and radiation hazard index from soil around repository facility at Bukit Kledang, Perak, Malaysia, in IOP Conference Series: Materials Science and Engineering, 2018, vol. 298, no. 1, p. 12001.

261 A. L. Rich and E. C. Crosby, Analysis of reserve pit sludge from unconventional natural gas hydraulic fracturing and drilling operations for the presence of technologically enhanced naturally occurring radioactive material (TENORM), New Solut., 2013, 23(1), 117-135.

262 J. E. Johnston, E. Lim and H. Roh, Impact of upstream oil extraction and environmental public health: a review of the evidence, Sci. Total Environ., 2019, 567, 187-199.

263 A. S. Saadoun and J. M. Rashid, Determination of Health Risk Coefficients for Natural Radioactive Elements in Crude Oil Produced from Al Gharraf Oil Field, Univesity of Thi-Qar Journal, 2018, 13(2), 42-60.

264 I. F. Vincent-Akpu, B. B. Babatunde and P. E. Ndimele, Occurrence of radioactive elements in oil-producing region of Nigeria, in The Political Ecology of Oil and Gas
Activities in the Nigerian Aquatic Ecosystem, Elsevier, 2018, pp. 149-158.

265 N. Afshar-Mohajer, M. A. Fox and K. Koehler, The human health risk estimation of inhaled oil spill emissions with and without adding dispersant, Sci. Total Environ., 2019, 654, 924-932.

266 J. Jonas, M. Hegedüs, J. Somalai and T. Kovacs, Applicability of Oil Industry Waste Product in Building Industry from Radiological Point of View, Radiation Environment and Medicine, 2018, 7(1), 28-36.

267 K. Al Nabhani and F. Khan, Chapter One - An overview of operational and occupational safety in onshore and offshore oil and gas extraction and production processes, Nuclear Radioactive Materials in the Oil and Gas Industry, 2020, pp. 1-49.

268 K. Al Nabhani and F. Khan, Chapter Eight - Conclusions and recommendations, Nuclear Radioactive Materials in the Oil and Gas Industry, 2020, pp. 259-282.

269 K. Al Nabhani, F. Khan and Y. Ming, Management of TENORMs produced during oil and gas operation, J. Loss Prev. Process Ind., 2017, 47, 161-168.

270 K. Al Nabhani and F. Khan, Chapter Five - Management of nuclear radioactive materials produced with oil and gas extraction and production, Nuclear Radioactive Materials in the Oil and Gas Industry, 2020, pp. 159-196.

271 K. Al Nabhani and F. Khan, Chapter Two - Fundamentals of technologically enhanced naturally occurring nuclear radioactive materials in the oil and gas industry, Nuclear Radioactive Materials in the Oil and Gas Industry, 2020, pp. 51-90.

272 K. Al Nabhani, F. Khan and Y. Ming, Scenario-based risk assessment of TENORM waste disposal options in oil and gas industry, J. Loss Prev. Process Ind., 2016, 40, 55-66.

273 K. Al Nabhani and F. Khan, Chapter Three - Risk assessment and management of TENORM waste disposal options in the oil and gas industry, Nuclear Radioactive Materials in the Oil and Gas Industry, 2020, pp. 91-123.

274 K. Al Nabhani, F. Khan and Y. Ming, Dynamic modeling of TENORM exposure risk during drilling and production, $J$. Pet. Explor. Prod. Technol., 2018, 8(1), 175-188.

275 K. Al Nabhani and F. Khan, Chapter Four - Quantitative risk assessment and dynamic accident modeling of TENORM occupational exposure in the oil and gas industry using SMART approach, Nuclear Radioactive Materials in the Oil and Gas Industry, 2020, pp. 125-175.

276 K. Al Nabhani, F. Khan and Y. Ming, The importance of public participation in legislation of TENORM risk management in the oil and gas industry, Process Saf. Environ. Prot., 2016, 102, 606-614.

277 K. Al Nabhani and F. Khan, Chapter Seven - The importance of public participation in legislation of TENORM risks management in the oil and gas industry, Nuclear Radioactive Materials in the Oil and Gas Industry, pp. 229-257, 2020.

278 UNSCEAR, Scientific Committee on the Effects of Atomic Radiation. Sources and effects of ionizing radiation: sources, United Nations Publications, New York: USA, 2000, vol. 1. 